\title{
Can Adaptive Market Hypothesis Explain the Existence of Seasonal Anomalies? Evidence from Dhaka Stock Exchange, Bangladesh
}

Tahmina Akhter ${ }^{1}$ and Othman Yong ${ }^{2}$

ABSTRACT

\begin{abstract}
This paper examines the behavior of seasonal anomalies in Dhaka Stock Exchange (DSE) of Bangladesh and whether the time varying nature of the anomalies is in line with Adaptive Market Hypothesis $(\mathrm{AMH})$. With this aim the research investigated whether the changes in market conditions, for example: up and down market states, stock market bubbles and crashes, initiation of automated trading system and circuit breaker system can affect the behavior of calendar anomalies and therefore, can provide justification for the seasonal patterns in DSE. To achieve the stated objectives, this study utilizes daily general index values of DSE from 1993 to 2018, with GARCH $(1,1)$ model, Markov switching model, subsample analysis and rolling window analysis. The findings support the existence of $\mathrm{AMH}$ at DSE in the form of time-varying nature of seasonal anomalies. However, not all seasonal anomalies examined in the study were found to grow weaker over time. The most important finding of this study is that the investors in emerging stock markets, for example DSE, may not learn from the past investment experiences and show the adapting ability towards changed market conditions in the same manner like the investors in a developed market.
\end{abstract}

KEY WORDS: $\quad$ Adaptive market hypothesis (AMH), market efficiency, seasonal anomalies, emerging stock market, Dhaka Stock Exchange.

JEL Classification: G10, G14, G41, P34.

${ }^{1}$ Assistant Professor, Faculty of Business Studies, University of Dhaka, Bangladesh

${ }_{2}^{2}$ Professor, Graduate School of Business, Universiti Kebangsaan Malaysia

\section{Introduction}

According to the Adaptive Market Hypothesis $(\mathrm{AMH})$ market efficiency and inefficiency can coexist in "a consistent and intellectually satisfying manner" (Lo, 2005, p. 22). This new framework $(\mathrm{AMH})$ reconciles market efficiency with behavioral alternatives by applying the "principles of evolution, competition, adaptation, and natural selection" (Lo, 2004, p. 2) to financial interactions. AMH does not consider market participants as perfectly rational or irrational, but as intelligent, future oriented

Correspondence concerning this article should be addressed to: Tahmina Akhter, Faculty of Business Studies, University of Dhaka, Bangladesh E-mail: tahmina_akhter@du.ac.bd and competitive investors who want to adapt to the changing economic scenario. It implies that during certain periods the stock returns are highly predictable and in some periods the markets are efficient. Empirical studies have shown that during economic bubbles, fundamental, economic, or political crises, return predictability and its uncertainty is smaller than normal times (Itoet al., 2016; Kim et al., 2011; Urquhart \& McGroarty, 2015). AMH claims that changing market conditions drive the key market features, for example: the return predictability (Kim et al., 2011). Moreover, each market adapts differently in certain market conditions (Urquhart \& McGroarty, 2015).

An interesting finding from the empirical works 
is that many well-known stock market anomalies in finance literature do not hold up in different sample periods (Agrawal \& Tandon, 1994; Urquhart \& McGroarty, 2015). However, some calendar effects still exist and if stock markets were efficient these anomalies would not exist (Thaler, 1987), or at least after their discovery in the academic research the abnormal profits related to anomalies should have been arbitraged away. Researchers have tried to explain these anomalous behaviors through theories, for example: tax loss hypothesis (Schultz, 1985), as a result of deviant pattern in investor psychology (Fama, 1998; Jacobs \& Levy, 1988; Lo, 2004, 2005, 2012), or simply due to the consideration of trading costs and impossibility of liquidation of entire trading portfolio on a particular day for the expectation of lower returns (Jacobs \& Levy, 1988). However, the debate on the actual causes of the anomalies is still going on. Some recent studies (Urquhart \& McGroarty, 2014) have shown that factors related to investors' personality and factors related to investors' specific environmental conditions, which are the major considerations of Adaptive Market Hypothesis (Lo, 2004), can influence their manners to incorporate new information into stock prices and determines how they will behave towards calendar anomalies.

With the above-mentioned facts about the calendar effects across the globe, the main objective of this study is to examine the time varying behavior of the seasonal anomalies in Dhaka Stock Exchange (DSE) of Bangladesh; and whether change in the market conditions of DSE can influence the behavior of anomalies over time to provide justification for these seasonal patterns, and thereby confirms the existence of the AMH in DSE. The stock market of Bangladesh is relatively new and still developing compared to other global markets. The fundamentals of the capital market of the country are very weak and fragile. In an emerging market like the DSE, where the market participants are often uninformed and suffer from lack of financial decisionmaking ability, high volumes, and rising prices are considered as signals of higher future stock prices (Jennings et al., 1981). The manipulators sometimes try to use these decision-making criteria (high volume and rising prices) of the uninformed investors to send deceptive signals to the market (Khwaja
\& Mian, 2005). This eventually can result in stock market bubbles and burst of the bubble (Azad et al., 2014). The capital market of Bangladesh has faced two major bubbles followed by market crashes that were mainly driven by panic and rumor. The first stock market bubble was formed in 1996 followed by a catastrophic crash. The capital market of Bangladesh again experienced a major slide in the year 2011. The Figure 1 presents the natural log values of the daily DSE general index values for the full sample period of January 1993 to December 2018 and the major economic, technological and regulatory changes that took place during this time that may influence the level of efficiency of the market and the time-varying behavior of the stock market anomalies.

The time series is showing an upward trend, with visible hikes in the year 1996 and 2010 when the DSE has experienced two stock market bubbles (shaded red area in the figure) in its history. The bubbles were followed by two stock market crashes as can be seen from the downward movement of the natural log values (shaded green area in the figure) of the DSE general index in Figure 1. The price limit was introduced on July 1, 1997 and the automated trading system was introduced in January 1, 2001 as indicated by the time bubbles in Figure 1.

From the stylized facts of the DSE it is comprehensible that the sample stock market of this study is quite different in terms of efficiency and level of development from any other stock markets of previous empirical studies conducted on developed markets in relation to AMH. Therefore, it would be interesting to examine the adapting nature of the market participants of an emerging stock market and to identify whether the less developed financial markets can adapt similarly like a developed market in changed market conditions. There are several other justifications for choosing DSE as the sample stock market. Firstly, developed markets have higher financial literacy. Since, DSE is dominated by small and noise investors (Azad et al., 2014) who lack financial awareness and has only 30 percent of foreign and institutional investors (Zaman \& Rahman, 2019). Therefore, the results of this study will help to understand whether the learning process and the adaptiveness suggested by $\mathrm{AMH}$, work in the 


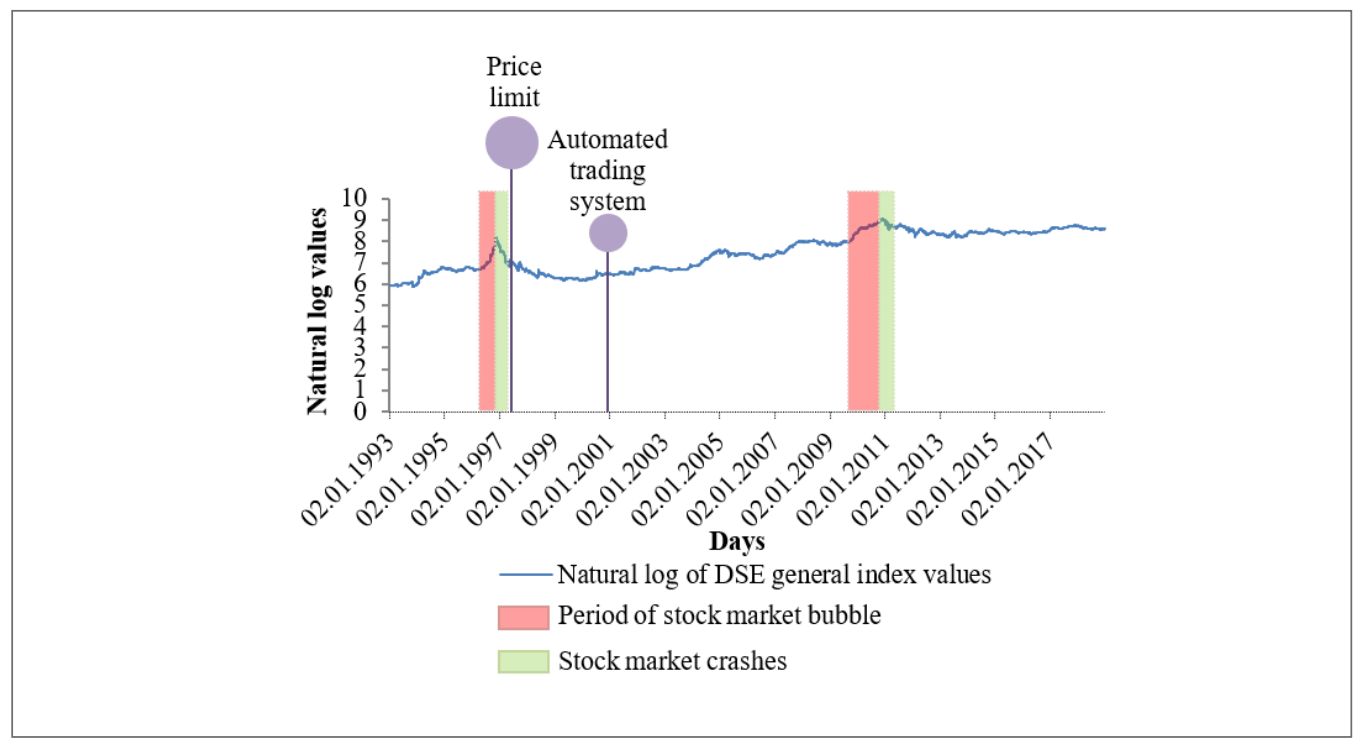

Figure 1. The general index values and the major stock market events from 1993 to 2018.

same manner in a market with lower financial literacy. Secondly, the market participants of DSE are expected to have dissimilar investment and trading decisions, compared to any other previous studies. Thirdly, although, DSE is attracting more foreign investors, it has not yet reached the level of sophistication and efficiency of developed markets. This may cause return patterns to be different in this market that are not addressed in literature. Finally, to understand the newly developed AMH theory and whether it works in all markets, this study will help to contribute to the further development of the $\mathrm{AMH}$ theory. In order achieve the stated objectives the study employed GARCH $(1,1)$ model and Markov switching regression analysis that can capture the underlying volatility of the returns of the DSE general index values from 1993 to 2018 .

The rest of the paper is organized as, following the introduction section, the next section reviews the existing literature and formulates the hypotheses for this study. Data and methodology section discusses the empirical methods of analysis and description of dataset. The next section presents the empirical results and findings. The final section concludes the paper, together with some closing remarks.

\section{Review of Related Literature}

In literature, existence of seasonal or calendar anomalies has always been considered as equivalent to non-existence of stock market efficiency (Boudreaux, 1995). According to the Random Walk Hypothesis (RWH) of Pearson (1905), stock returns should not have any memory and a professional stock value analyst should not be able to generate higher profit compared to naive buy hold strategy of stocks (Fama, 1965). When the markets are efficient, security prices should fully reflect all available information (AlSaad \& Moosa, 2005), and in this case earning above average return from the available set of information is not possible (Fama, 1970). However, the extensive empirical evidence of stock market anomalies across the globe poses a clear incongruity on Efficient Market Hypothesis (EMH) of Fama (1970). According to the proponents of al finance the market participants show a discrepancy regarding their expectations (Shiller, 1999, 2003) across time and different markets. On the contrary, the AMH states that all stock markets experience period of inefficiencies, where such anomalous profit opportunities are available some periods the and in other periods the stock markets follow the random walk. 


\subsection{Adaptive Market Hypothesis in Emerging Economies}

A few number of studies examined the time varying efficiency under the framework of AMH in developing or emerging economies over the past decade. Lim and Brooks (2006) utilized portmanteau bicorrelation test statistic of Hinich (1996) in a rolling sample approach to capture the evolution of market efficiency over time by using all countries' stock index returns from MSCI (for 23 developed and 27 emerging stock markets) and found that the degree of time variant market efficiency is in line with AMH. Moreover, the stock markets of developed countries are relatively more efficient compared to those of emerging countries (apart from few exceptions). Todea et al. (2009) investigated the profitability of the moving average strategy of six Asian capital markets considering the episodic character of linear and nonlinear dependencies, for year 1997 to 2008 and they concluded that profitability of moving average strategies is not constant over time, rather it is episodic; where sub-periods of linear and non-linear correlation appeared that suggests the existence of AMH. Dyakova and Smith (2013b) tested the martingale hypothesis for two Bulgarian stock indices and eight stock prices using finite sample variance ratio test in a rolling window from October 2000 to August 2012 and confirmed that predictability of the stock prices supports the AMH and the stock market becomes more predictable during financial crisis. Niemczak and Smith (2013) studied 11 Middle Eastern stock markets and showed that most markets experience successive periods of efficiency and inefficiency, which is consistent with the AMH. Hull and McGroarty (2014) used the Hurst-Mandelbrot-Wallis rescaled range test as a measure of market efficiency on 22 emerging markets and showed strong evidence in favour of $\mathrm{AMH}$; also, as the markets become more advanced they become more efficient. Smith and Dyakova (2014) used a rolling window analysis on three finite-sample variance ratio tests to examine the changing predictability of African stock market returns and found that stock markets go through successive periods of predictability and unpredictability that is consistent with the AMH. Ghazani and Araghi (2014) examined daily data from Tehran stock exchange from year 1999 to 2013 and found that $\mathrm{AMH}$ provides a suitable explanation for market efficiency.

Therefore, the empirical evidence from the financial markets that are considered as developing or emerging support the existence of AMH. However, the market conditions that trigger the level of efficiency to evolve over time in a specific stock market varies across markets.

\subsection{Seasonal Anomalies}

In this study four major seasonal anomalies with significant predictive ability, which are evident in the literature of emerging stock markets and in the DSE are selected. The anomalies that are analyzed in this study are beginning day of week and Thursday effect, June effect, Ramadan effect, Eid-ul-Fitr and Eid ulAdha pre- and post-holiday effects. For these calendar anomalies, in literature stock returns are found to be systematically higher or lower depending on the day of the week, or month of the year.

\subsubsection{Beginning Day of Week and Thursday Effect}

One frequently tested claim regarding day seasonality is that returns are predictable and above or below average, on certain days of a week. Day seasonality has several variant formulations. The standard Monday effect suggests that Monday's returns are lower than those for Tuesday through Friday (French, 1980; Kamara, 1997); the weekend effect examines the difference between returns for Mondays and Fridays alone (Cross, 1973); and the weekday effect or, dayof-week effect (Doyle \& Chen, 2009) is simply that weekdays differ in their expected returns. However, some studies after discovering the weekend effect shows that the anomalies are fading away (Alt et al., 2011; Marquering et al., 2006) or in some case reversing (Brusa et al., 2000, 2005). By using daily index returns of DSE, Rahman (2009) and Iqbal and Roy (2015) found statistically significant positive return on the last day of week, Thursday; where, the earlier study reported statistically significant negative return on Sundays and the later study observed the negative returns on Mondays. In another study on the DSE daily index values by Hassan and Khan (2019) stated that the negative returns on Sundays are incorporated with the highest trading volatility and lowest trading 
volume in the stock market. In the Chittagong Stock Exchange (CSE) Islam and Sultana (2015) also found the negative Sunday effect and positive Thursday effect. Therefore, for the day of week anomaly and their time-varying behavior over time is expressed in form of testable hypotheses as follows:

Hypothesis 1: The mean returns of the day-of-week anomaly are different from the non-anomaly days. Hypothesis 1a: The day of week effect in the DSE will disappear over time.

\subsubsection{Holiday effects}

The holiday effect is all about the investors' behavior before and after the holidays and holiday here means the day on which trading was closed because of any local cultural or religious festival. In case of the holiday effect, the cultural influences (Wachtel, 1942) are considered to be vital and for countries where Islamic culture is important researchers need to look at the Islamic calendar for stock market anomalies (Chan et al., 1996). As Bangladesh is a Muslim majority country, Islam influences the major holidays along with the life of people in this country. In a study on Malaysian market from year 1970 to 1985 Wong et al. reported a negative preholiday effect for Eid-ul-Fitr. In their study on the stock markets of Malaysia, Singapore, Thailand and India from year 1975 to 1991, Chan et al. (1996) also found strong preholiday effect for cultural and religious holidays. Bley and Saad (2010) in a study on the Gulf Cooperation Council (GCC) region found statistically significant preholiday effect for Eid-ul-Fitr in all GCC countries, except for Bahrain and Eid-ulAdha effect for Kuwait and Bahrain. Zafar et al. (2012) found statistically significant preholiday effect for Eidul-Fitr, Eid-ul-Adha and six other public holidays in the stock market of Pakistan for year 1991 to 2007, where majority of the investors are local and Muslim.

The two main holidays of Bangladesh are Eid-ulFitr and Eid-ul-Adha. For both religious festivals the country observes at least three days of holidays and the government and non-government organizations give festive bonuses (which is mandatory according to Bangladesh Labour Rules 2015) to their employees on these festive occasions. Therefore, the hypotheses for pre and post holiday effects and their time-varying behavior are formulated as follows:
Hypothesis 2: The mean returns for pre- and postholidays are different from non-pre- and post-holiday returns.

Hypothesis 2a: The pre- and post-holiday effects will disappear from DSE over the course of time.

\subsubsection{June Effect}

Calendar anomalies and January effect was first reported by Wachtel (1942). He examined the seasonality in the Dow Jones Industrial Average (DJIA) Index from year 1927 to 1942 and found frequent bullish tendencies from December to January in eleven out of the fifteen years he studied. However, January effect is not evident from the empirical studies in DSE, instead the June effect was found to exist in case of Bangladesh (Ahsan \& Sarkar, 2013). The June effect suggests that a statistically significant positive return exists in the month of June compared to other months of the year. The plausible reason for the existence of this anomaly can be that the tax year for the country is from July to June, so investors start to invest more in stock market and government securities to get tax rebate. Ahsan and Sarkar (2013) reported negative mean stock return for months December to April and positive return in June. Therefore, the hypotheses for June effect and its timevarying effects are formulated as follows:

Hypothesis 3: The monthly average mean returns for the month of June are different compared to other months of the year.

Hypothesis 3a: The June effect will gradually fade away from DSE over time.

\subsubsection{Ramadan Effect}

Ramadan, which is observed by more than 1.5 billion Muslims, is one of the most celebrated religious traditions in the world. Ramadan is the time for self-reflection, behavioral improvements, charity, and worship of Allah (Qur'an 51:21; 2:183). This positive attitude towards life obtained from the month of Ramadan can encourage the investors to have an optimistic mindset for investments, which is observed for other religious events across the world (Al-Hajieh et al., 2011; Al-Khazali, 2014; Białkowski et al., 2012). But, Seyyed et al. (2005) examined the behavior of the Saudi Arabian stock market in Ramadan for year 1985 to 2000 and found no significant change in mean return but a 
noticeable decline in volatility. Bangladesh is world's fourth largest Muslim country, where $89.1 \%$ of the population are Muslims (Central Intelligence Agency, 2021). However, Hassan and Kayser (2019) observed no significant relationship of the returns in Raman market returns and volatility in DSE; moreover, the study found that Ramadan has a significant negative impact on the daily trade volume of DSE. Recently in a study conducted by Gavriilidis et al. (2015) examined whether the positive mood documented during the Ramadan translates into higher herding compared to non-Ramadan with data from stock markets of seven largest Muslim countries in the world. Their study showed statistically significant herding behavior in case of Bangladesh during Ramadan that may be due to positive mood during this holy month. Nevertheless, since, Ramadan effect cannot be traced in several stock markets with majority Muslim participants, other factors, for example economic conditions of the market, investors' al patterns etc., may also contribute towards this anomalous return pattern during this month. Therefore, the hypotheses for Ramadan effect and it's time varying behavior are formulated as follows:

Hypothesis 4: The monthly average mean returns for the month of Ramadan are different compared to other months of the year.

Hypothesis 4a: The Ramadan effect will disappear over time.

\subsection{Changing Market Conditions and Calen- dar Anomalies}

Though AMH implies that the degree of stock return predictability depends on market conditions, it does not provide any theoretical guidance on how to choose the market conditions for different markets. The evolving system in the $\mathrm{AMH}$ does not essentially mean that security prices should move towards equilibrium (Lo, 2005). The empirical evidence on the abnormal return patterns during bullish (up) and bearish (down) market conditions suggest that the anomalies vary during different market conditions (Cui et al. , 2008; Hiraki \& Maberly, 2003). Some of the anomalies generate statistically significant abnormal returns during only up or down market states. Therefore, the seasonal anomalies are expected to vary in their nature and extent de- pending on the up or down market conditions. However, the nature of the responses towards these market states may differ from other stock markets (Lo 2005).

DSE faced some major changes in its macro environment over the past two decades including two major stock market bubbles and crashes: the first one in the year 2006 (speculative bubble) and again during late 2009 and early 2010 (asset bubble). Empirical studies have shown that during economic bubbles, fundamental, economic, or political crises, return predictability and its uncertainty are smaller than normal times (Ito et al., 2016; Kim et al., 2011; Urquhart \& McGroarty, 2015). After three months of the first stock market crash, the Securities and Exchange Commission of Bangladesh (BSEC) introduced the circuit breaker system in the form of trade halt and price limits.

Although the circuit breaker systems are believed to increase the level of market efficiency (Bo \& Yong, 2009), but some empirical evidence indicate that imposition of circuit breakers can create imbalance in stock prices by hindering the closing price of the stock to reflect its true value (Kim \& Yang, 2004). DSE introduced automated trading system from January 2001 to reduce the noise trading and unnecessary volatility during crisis period. Automation is supposed to enhance the price discovery, that is, the speed and efficiency of reflection of new information into stock prices (Boehmer \& Kelley, 2009; Chordia et al., 2008). As automation is believed to reduce the transaction costs, it also should ensure efficient security allocation among investors, improve security risk fluctuations and raise the price of securities (Acharya \& Pedersen, 2005; Pástor \& Stambaugh, 2003). Therefore, the following hypotheses are formulated to examine the influence of change in market condition of DSE on the behavior of calendar anomalies:

Hypothesis 5: Calendar effects vary between the up and down market states.

Hypothesis 6: Calendar effects vary among the periods of stock market crashes, bubbles, and normal periods.

Hypothesis 7: Calendar anomalies vary between the pre and post circuit breaker imposition periods.

Hypothesis 8: Calendar effects vary between pre and post automated trading system initiation periods. 


\section{Data and Methodology}

The sample in this study comprises the general index values of DSE from January 1993 to December 2018. Data for this study is collected from DSE library. The study employs daily adjusted closing prices of the DSE general index- DGen and DSEX (DSEX replaced DGen from 27 January 2013) index. The index is a price weighted average of all listed stocks on Dhaka Stock Exchange. For further analysis and to minimize the probability of the existence of autocorrelation problem in the time series data the first difference of natural log prices have been calculated from the daily index values:

$$
R_{t}=\left[\ln \left(P_{t}\right)-\ln \left(P_{t-1}\right)\right]
$$

In Equation (1), $R_{t}$ is the first difference of natural logarithm value of the general index at period $t, \ln \left(P_{t}\right)$ is the natural logarithm value of the index at period $t$, and $\ln \left(P_{\mathrm{t}-1}\right)$ is the natural logarithm of the index at time $t-1$.

To capture calendar anomaly effects and the effects of changing market conditions on seasonal market anomalies, the following regression equation is estimated:

$$
R_{t}=c+\beta D_{t}+\varepsilon_{t}
$$

where, $\mathrm{t}=1,2,3, \ldots, \mathrm{T}$

In Equation (2), $R_{t}$ is the return on stock index, $D_{t}$ is the dummy independent variable, where the calendar anomaly days or specific market conditions are denoted as ' 1 ' and otherwise ' 0 ' and $\varepsilon_{t}$ is the error term. The dummy independent variable will help to capture the nature and extent of influence of a particular calendar period, (Agrawal \& Tandon, 1994; Jacobsen \& Zhang, 2013; Keef \& Roush, 2005; Kim \& Park, 1994; Urquhart \& McGroarty, 2014) or market condition (Kim et al., 2011; Lim \& Brooks, 2009; Lim, Brooks, \& Kim, 2008b; Urquhart \& McGroarty, 2014).

The Generalized Autoregressive Conditional Heteroscedasticity (GARCH) model is used in this study to estimate Equation (2) instead of the ordinary least square (OLS) model. OLS assumes that the volatilities of the error terms are constant (homoscedastic), since OLS aims to minimize the deviations between data points and a fitted regression line. However, if the variances of the error terms are not equal, it can result in selection of an inappropriate econometric model. According to Engle (2001), GARCH $(1,1)$ is "the simplest and most robust of the family of volatility models", and is also most widely used in literature, as it can be extended and modified in different ways according to the needs of the researcher. Therefore, the current study mostly employed the GARCH $(1,1)$ models for the analysis of calendar anomalies for which the variance equation can be stated as follows:

$\sigma_{t}^{2}=\omega+\theta \sigma_{t-1}^{2}+\alpha \epsilon_{t-1}^{2}$

As in Equation (3), $\sigma_{t}^{2}$ represents the forecasted variance one period ahead, therefore, the equation is called the conditional variance equation and $\theta$ and $\alpha$ are GARCH model coefficients. In a study on DSE general index returns by Roni, Wu, Jewel, and Wang (2017) reported that GARCH model is more efficient with higher forecasting ability indicated by the statistic error measurements of the model in this stock market.

After applying the GARCH (1,1) model, the correlogram Q-statistics and the correlogram squared residuals are employed to identify the serially correlated lags in the error terms. The correlogram Q-statistics of residual diagnostic allows plotting the autocorrelations and the partial autocorrelations of the standardized residuals up to a specific number of lags, along with the Q-statistic values with the corresponding $\mathrm{p}$ values; where a $\mathrm{p}$ value of less than 5 percent indicates the presence of potential autocorrelation problem in the error terms. To identify the ARCH effect in the time series data the Lagrange multiplier (LM) test for autoregressive conditional heteroscedasticity (ARCH) in the residuals (Engle, 1982) of a regression model is applied.

To evaluate whether the GARCH $(1,1)$ model could capture the non-linear structure in the return series, the BDS test is used on the standardized residuals as a misspecification test. The acceptance of the Independent and Identical Distribution (I.I.D.) hypothesis implies that the conditional heteroscedasticity is responsible for the non-linearity in index returns. The study tests for the non-linear dependence in stock returns, by applying the BDS 
test developed by Broock et al. (1996), which is based on the null hypothesis of IID to the logarithm of the squared standardized residuals from the GARCH process. According to Brock and Potter (1993) and De Lima (1996) BDS test is more reliable if it is applied to the logarithms of squared standardized residuals from a fitted GARCH model.

Depending on the multi-break (Bai \& Perron, 1998, 2003) unit root test the study applies the Markov switching regression (Hamilton, 1989, 2010) that allows for the periodic structural shifts in the parameters that describe the system's dynamics and volatility. The first-order Markov assumption indicates that the previous state influences the probability of remaining in a regime, so that:

$$
P\left(s_{t}=j \mid s_{t-1}=i\right)=p_{i j}(t)
$$

where, $s_{t}$ is the current state and $s_{t-1}$ denotes the previous state. Usually, the probabilities are assumed as time-invariant, as a result $\mathrm{p}_{\mathrm{ij}}(\mathrm{t})=\mathrm{p}_{\mathrm{ij}}$ for all $t$, and this restriction is not required. The transition matrix for these probabilities can be written as:

$P(t)=\left[\begin{array}{ccc}p_{11}(t) & \ldots & p_{1 M}(t) \\ \cdot & \ldots & \cdot \\ p_{M 1}(t) & \ldots & p_{M M}(t)\end{array}\right]$

where, the $i j$-th element represents the probability of transitioning from regime $i$ in period $t$ - 1 to regime $j$ in period $t$. In the simple switching model, the probabilities can be parameterized in terms of a multinomial logit. Since, each row of the transition matrix specifies a full set of conditional probabilities, a separate multinomial specification for each row of the matrix is defined as follows:

$$
\mathrm{P}_{\mathrm{ij}}\left(\mathrm{G}_{\mathrm{t}-1}, \delta_{\mathrm{i}}\right)=\frac{\exp \left(\mathrm{G}_{1-1}^{\prime} \delta_{1 \mathrm{j}}\right.}{\sum_{\mathrm{s}=1}^{\mathrm{M}} \exp \left(\mathrm{G}_{\mathrm{t}-1}^{\prime} \delta_{\mathrm{is}}\right)},
$$

where, $j=1, \ldots . ., M$ and $i=1, \ldots \ldots ., M$ with the normalizations $\delta_{\mathrm{iM}}=0$. Markov switching models are usually specified with constant probabilities, therefore, $\mathrm{G}_{\mathrm{t}-1}$ contains only a constant. The model specified by Hamilton (1989) on GDP is an example of a constant transition probability specification.

This research uses subsample analysis as well as rolling window analysis (Charles, Darné, \& Kim,
2012; Dyakova \& Smith, 2013a, 2013b; Lim \& Brooks, 2006; Lim, Luo, \& Kim, 2013; Smith, 2012; Urquhart \& Hudson, 2013; Urquhart \& McGroarty, 2014, 2016). The subsample analysis helps to examine the behavior of calendar anomalies over time for each subsample; however, the choice of size of subsample is subjective and some time-varying behavior of the seasonalities can be lost. This study determines the sub-samples depending on the break dates determined by the Bai and Perron (1998) structural break test. Bai and Perron (1998) described global optimization procedures for identifying the multiple breaks which minimize the sums-of-squared residuals of the specified regression model. Therefore, for a specific set of $\mathrm{m}$ breakpoints, for instance, $\{T\}_{m}=\left(T_{1}, T_{2}, \ldots, T_{m}\right.$, the sum-of-squared residuals can then be minimized as follows:

$\mathrm{S}(\beta, \delta \mid\{\mathrm{T}\})=\sum_{\mathrm{j}=0}^{\mathrm{m}}\left\{\sum_{\mathrm{t}=\mathrm{T}_{\mathrm{j}}}^{\mathrm{T}_{\mathrm{j}+1}-1} \mathrm{y}_{\mathrm{t}}-\mathrm{X}_{\mathrm{t}} \beta-\mathrm{Z}_{\mathrm{t}}^{\prime} \delta_{\mathrm{J}}\right\}^{2}$

In Equation (7) standard least squares regression is used to obtain estimates of $\beta$ and $\delta$. The global $m$-break optimizers are the set of breakpoints and corresponding coefficient estimates that minimize sum-of-squares across all possible sets of $m$-break partitions.

The time-varying framework permits to identify (Lim et al., 2008a) the nature and pattern of anomalous behavior in a particular stock market. However, there is no specific theory behind the process of selection of the window length in the rolling window analysis. According to Timmermann (2008), the shorter windows can capture the variability of the returns better that often can be missed if the window size is too long. Nevertheless, the window size also should be large enough so that the statistical tests employed in the study do not suffer from lack of power or size distortion. The current study covers the time period of January 1993 to December 2018 for the calendar effects and the sample period of January 1995 to December 2018 for the momentum effects, using a fixed five-year length window with one year rolling forward each time. A five-year window employed by the current study has enough observations for the ARCH type models to generate reliable results, while also generating enough results to enable a detailed examination of the of calendar anomalies over time (Kim et al., 
2011; Urquhart \& McGroarty, 2014). To examine the time-varying behavior of the calendar anomalies the Equation (2) is applied for the rolling window analysis. By plotting the $z$-values (calculated as $\beta$-coefficient/ Standard Error) from GARCH $(1,1)$ regression results over time for each of the seasonal effects, we can find the pattern of the time-varying behaviors of these anomalies and whether their behavior patterns show that the anomalies are becoming statistically insignificant over time.

To capture the pre and post influence of each event on calendar anomalies in different market conditions (for example: stock market crashes and bubbles, impact of circuit breaker and automated trading system) the sub-sample analysis is used. After dividing the whole sample period into up and down months, stock market bubbles, crashes and normal periods, pre and post automated trading system initiation periods, and pre and post circuit breaker imposition periods the Equation (2) is applied to investigate the day of week effect, month of year effect and the holiday effect during these different market conditions of the DSE.

\section{Empirical Results}

\subsection{Descriptive Statistics}

This section focuses on data analysis results. The daily returns of DSE general index from year 1993 to year 2018 is presented in Figure 2. The movement pattern of the return series shows that the series has time dependence. Also, the variability is not uniform and the time series has occasional spikes, which is a very common characteristic of a stock index returns (Mikosch \& Starica, 2004).

The descriptive statistics of the daily general index returns presented in Table 1 for the full sample period of 1993 to 2018 shows that the time series has a daily mean return of 0.04 percent, while the standard deviation of returns is 1.48 percent. The data series has excess kurtosis (48.68) and positive skewness (0.9224). The Augmented Dickey Fuller test (ADF) statistics at level for general index returns show that the data series does not have a unit root.

The Bai-Perron structural break test indicates that the first difference of natural log of the daily stock index

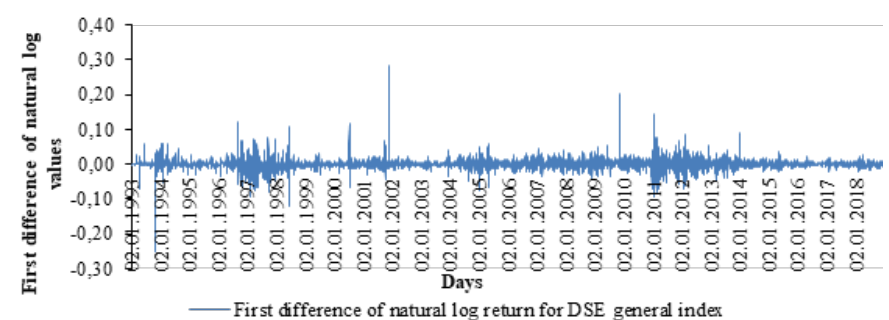

- First difference of natural $\log$ return for DSE general index

Figure 2. The daily natural log values of DSE general index from year 1993 to 2018. 
Table 1. Descriptive Statistics for DSE General Index Returns for Sample Period of Year 1993 to 2018

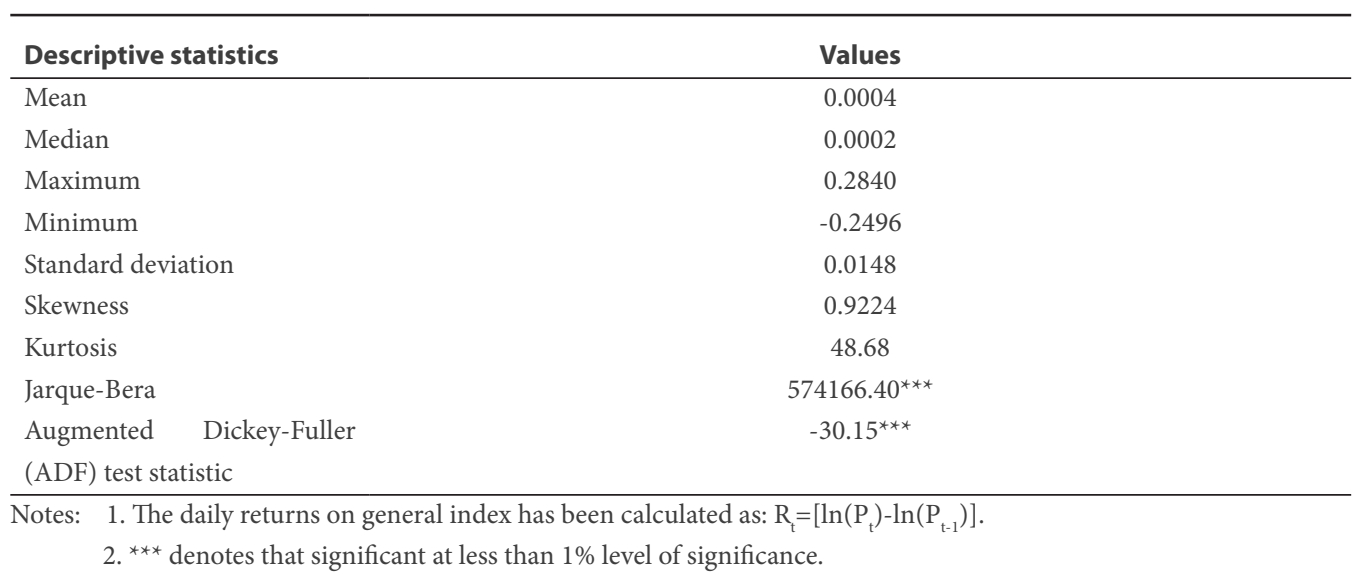

values have two statistically significant break dates presented in Table 2. The break point unit root test also confirms that it is necessary to break the time series on these two dates to generate stationary time series of the first difference of natural log of the daily stock index values in DSE.

Table 3 presents descriptive statistics for different calendar anomaly days and non-anomaly days. The mean returns of calendar anomaly days compared to non-anomaly days can give us a rough idea about the nature of return patterns from a specific calendar effect in comparison to non-calendar effect days. Descriptive statistics for full sample period reveal that the beginning days of a week have lower average returns compared to non-beginning days of a week. Moreover, since September 2005 (when the beginning days of the week were Sundays) the mean return has become negative, where the average return for non-Sundays is positive. This return pattern shows that the DSE has recently had negative returns on the beginning days of a week.

The Thursdays produce positive and higher average rates compared to the non-Thursdays of a week. The mean returns for Junes are also higher compared to non-June months of a year. Although the average return during Ramadan days is positive, but it is not lower compared to the average return of non-Ramadan months of a Hijri year. As shown in Table 3 the average pre-holiday returns for Eid-ul-Adha are positive and higher than non pre-holiday average returns in DSE. Lastly, the pre- and post-holiday average returns for Eid-ul-Fitr are positive and higher compared to the other non-holiday average returns in the DSE.

\subsection{Results for Full and Sub-samples for Differ- ent Calendar Anomalies}

Table 4 presents the regression results for the full samples for the calendar anomalies in the DSE from GARCH $(1,1)$ and Markov switching models. The diagnostic tests for the GARCH models are presented in Appendix A. The diagnostic tests include the normality test, autocorrelation and heteroscedasticity of the residuals from the regression analysis of the time series data to show the reliability of the regression analyses. A statistically insignificant JB statistics is expected to accept that the residuals are normally distributed. However, it is evident from the Appendix A that the residuals from the regression models are not normally distributed. Although, normality in the distribution of the residuals is desired, but it is a stylized and normal situation for the ARCH and GARCH regression models with financial time series data. To identify the order of serial correlation, the correlogram Q-statistics along with the serial correlation Lagrange Multiplier (LM) statistics are calculated to find out the number of serially correlated lags (for the LM test three lags are considered) from the Eviews-9.5 software. After the GARCH $(1,1)$ models are estimated the ARCH 
Table 2. The Structural Break Dates of the Time Series First Difference of Natural Logs of Daily Index Values from January 1993 to December 2018 from Bai-Perron Test

\section{Break dates from Bai-Perron structural break test t statistics of break point unit root test}

$4 / 11 / 1996$

$6 / 12 / 2010$

\section{$-13.01^{* *}$}

$-12.04^{* *}$

Note: $1 .{ }^{*},{ }^{* *}$ and ${ }^{* * *}$ indicates level of significance at less than $10 \%, 5 \%$ and $1 \%$ level.

Table 3. Descriptive Statistics for Full Sample

\begin{tabular}{lccc}
\hline & Mean & Standard deviation & No. of days \\
\hline First difference of log return & $0.0430 \%$ & $1.4681 \%$ & 6,333 \\
Beginning days of week (Saturdays and Sundays) & $-0.0500 \%$ & $1.5574 \%$ & 1,123 \\
Non-beginning days of week & $0.0630 \%$ & $1.4478 \%$ & 5,210 \\
Thursdays & $0.2357 \%$ & $1.2143 \%$ & 1,130 \\
Non-Thursdays & $0.0011 \%$ & $1.5148 \%$ & 5,203 \\
June & $0.1885 \%$ & $1.2959 \%$ & 558 \\
Non-June & $0.0289 \%$ & $1.4841 \%$ & 5,775 \\
Ramadan & $0.0091 \%$ & $1.3472 \%$ & 523 \\
Non-Ramadan & $0.0431 \%$ & $1.4967 \%$ & 5,810 \\
Bangla New Year post-holidays & $-0.0421 \%$ & $1.3615 \%$ & 100 \\
Non Bangla New Year post-holidays & $0.0443 \%$ & $1.4700 \%$ & 6,233 \\
Eid-ul-Fitr pre-holidays & $0.2826 \%$ & $0.9908 \%$ & 196 \\
Non Eid-ul-Fitr pre-holidays & $0.0357 \%$ & $1.4731 \%$ & 6,137 \\
Eid-ul-Fitr post-holidays & $0.4503 \%$ & $1.0457 \%$ & 78 \\
Non Eid-ul-Fitr post-holidays & $0.0379 \%$ & $1.4722 \%$ & 6,255 \\
Eid-ul-Adha pre-holidays & $0.3858 \%$ & $0.9637 \%$ & 104 \\
Non Eid-ul-Adha pre-holidays & $0.0373 \%$ & $1.4747 \%$ & 6229 \\
\hline
\end{tabular}

(LM) test is used to test the autoregressive conditional heteroscedasticity $(\mathrm{ARCH})$ effect in the residuals of the regression models that is estimated from the observed $\mathrm{R}^{2}$ of the test and their corresponding probability value. The statistically insignificant chi-squares from the ARCH (LM) at more than 5 percent level of significance indicate that the residuals of the estimated GARCH models are homoscedastic. Therefore, the outcomes of these regression models can be considered as efficient for inferences. Moreover, the statistically significant coefficients of the conditional variance equation in Appendix A, confirm that the residual variances can be successfully captured by the regression models. The formulated GARCH models are also stable as the summation of the ARCH and GARCH coefficients are less than unity.

The beginning day of week was Saturday until 3rd September, 2005 and it is Sunday since 10th September, 2005. From the regression results presented in Table 4, we can find that for the full sample period the returns on the beginning days of a week are negative and statistically significant compared to non-beginning days of a week. On the other hand, the Thursday effect is positive and statistically significant for the whole sam- 
ple period at less than 1 percent level of significance. The GARCH $(1,1)$ model indicates that June effect is positive and statistically significant for the full sample period of 1993 to 2018. As it can be found from the $\beta$-coefficient of the conditional mean equation the Ramadan effect is not statistically significant for the full sample period considering 5 percent level of significance. Eid-ul-Fitr, which is the most important national and religious holiday for the people of Bangladesh, is found to have statistically significant preand post-holiday effect on the DSE for the observed sample period of 1993 to 2018. As presented in Table 4 the second major religious holiday of Bangladesh, Eidul-Adha, generates positive and statistically significant preholiday effect for the sample period from 1993 to 2018 compared to non-preholiday returns. However, the BDS independence tests of the assumed GARCH $(1,1)$ models presented in Appendix A, indicate that except for the model of June effect all other models reject the I.I.D. null hypothesis. This indicates that the volatility modeling by the GARCH models cannot remove the non-linearity in the log of squared residuals of the estimated models. It is worth noting that the rejection of I.I.D can be influenced by regulatory reforms or regime change among many other plausible factors that influences the non-randomness (Brock \& Potter, 1993).

The coefficients from the Markov switching model in Table 4 indicates that the beginning day of week effect, June effect, Eid-ul-Fitr preholiday effect and Eidul-Adha pre- and post-holiday effects are statistically significant in the high volatility period of the DSE but not during the low volatility period. The ending day of week effect is significant at less than 1 percent level in both high and low volatility regimes. However, the Ramadan effect is not statistically significant in any of the regimes. In general, the finding is consistent with the GARCH model.

The sub-samples for the calendar anomaly analysis are decided based on the structural break dates determined from the Bai-Perron test that are illustrated in Table 5. The sub-sample results reveal that the begin-

Table 4. Regression Results for the Full Samples of Calendar Anomalies

\begin{tabular}{lcccccc}
\hline Anomaly & \multicolumn{2}{c}{$\begin{array}{c}\text { GARCH (1,1) condi- } \\
\text { tional mean equation }\end{array}$} & \multicolumn{3}{c}{ Markov switching model } \\
\hline & C & B & \multicolumn{2}{c}{ High volatility regime } & Low volatility regime \\
\cline { 3 - 7 } Beginning day of week effect & $-0.0004^{* * *}$ & $-0.0007^{* * *}$ & $-0.0006^{* *}$ & $-5.04^{* * *}$ & -0.0026 & $-3.70^{* * *}$ \\
& $(-5.68)$ & $(-4.79)$ & $(-1.99)$ & $(-130.16)$ & $(-1.57)$ & $(-64.68)$ \\
Ending day of week effect & $0.0001^{*}$ & $0.0009^{* * *}$ & $0.0012^{* * *}$ & $-5.07^{* * *}$ & $0.0048^{* * *}$ & $-3.72^{* * *}$ \\
& $(1.71)$ & $(5.56)$ & $(4.68)$ & $(-162.69)$ & $(3.72)$ & $(-70.50)$ \\
June effect & $0.0002^{* *}$ & $0.0018^{* * *}$ & $0.0379^{* * *}$ & $-2.91^{* * *}$ & -0.0642 & $-1.59^{* * *}$ \\
Ramadan Effect & $(2.52)$ & $(8.93)$ & $(3.00)$ & $(43.93)$ & $(-0.74)$ & $(-10.13)$ \\
Edi-ul-Fitr Preholiday effect & $0.0002^{* *}$ & $0.0005^{*}$ & -0.0001 & $-2.87^{* * *}$ & 0.0089 & $-1.32^{* * *}$ \\
& $(2.11)$ & $(1.66)$ & $(-0.01)$ & $(-41.28)$ & $(0.09)$ & $(4.97)$ \\
Eid-ul-Fitr Post-holiday effect & $0.0002^{* * *}$ & $0.0033^{* * *}$ & $0.0032^{* * *}$ & $-5.05^{* * *}$ & 0.0015 & $-3.62^{* * *}$ \\
& $(3.35)$ & $(8.50)$ & $(5.23)$ & $(-159.81)$ & $(0.33)$ & $(-46.66)$ \\
& $0.0002^{* *}$ & $0.0029^{* * *}$ & $0.0013^{*}$ & $-5.05^{* * *}$ & 0.0043 & $-3.62^{* * *}$ \\
Eid-ul-Adha Preholiday effect & $(2.35)$ & $(4.20)$ & $(1.67)$ & $(-159.22)$ & $(1.11)$ & $(-46.48)$ \\
& $0.0002^{* *}$ & $0.0027^{* * *}$ & $0.0026^{* * *}$ & $-5.05^{* * *}$ & -0.0019 & $-3.62^{* * *}$
\end{tabular}

Note: $\quad 1 .{ }^{*},{ }^{* *}$ and ${ }^{* * *}$ indicates level of significance at less than $10 \%, 5 \%$ and $1 \%$ level.

2 . The respective $z$ values and $t$ values are within the parentheses. 
Table 5. Regression Results for the Sub-Samples of Calendar Anomalies

\begin{tabular}{|c|c|c|c|c|c|c|}
\hline \multirow[t]{3}{*}{ Anomaly } & \multicolumn{6}{|c|}{ GARCH $(1,1)$ conditional mean equations for different sub-samples } \\
\hline & \multicolumn{2}{|c|}{$2 / 1 / 1993$ to $3 / 11 / 1996$} & \multicolumn{2}{|c|}{$4 / 11 / 1996$ to $15 / 7 / 2010$} & \multicolumn{2}{|c|}{$18 / 7 / 2010$ to $27 / 12 / 2018$} \\
\hline & $\mathrm{C}$ & B & C & B & $\mathrm{C}$ & B \\
\hline Beginning day of week effect & $\begin{array}{c}-0.0003^{* *} \\
(-1.98)\end{array}$ & $\begin{array}{l}0.0001 \\
(0.33)\end{array}$ & $\begin{array}{c}0.0005^{\star * *} \\
(5.81)\end{array}$ & $\begin{array}{l}-0.0003 \\
(-1.02)\end{array}$ & $\begin{array}{c}-0.0011 \\
(-8.64)\end{array}$ & $\begin{array}{c}-0.0028^{* * *} \\
(-8.40)\end{array}$ \\
\hline Ending day of week effect & $\begin{array}{c}0.0008^{* *} \\
(2.96)\end{array}$ & $\begin{array}{c}0.0021^{\star * *} \\
(3.35)\end{array}$ & $\begin{array}{c}-0.0001 \\
(-0.83)\end{array}$ & $\begin{array}{c}0.0010^{\star * *} \\
(3.11)\end{array}$ & $\begin{array}{c}0.0004^{* * *} \\
(5.34)\end{array}$ & $\begin{array}{c}0.0016^{* * *} \\
(7.92)\end{array}$ \\
\hline Edi-ul-Fitr Preholiday effect & $\begin{array}{c}0.0003^{*} \\
(1.78)\end{array}$ & $\begin{array}{c}0.0019^{*} \\
(1.72)\end{array}$ & $\begin{array}{c}0.0007^{* * *} \\
(3.23)\end{array}$ & $\begin{array}{c}0.0039^{* * *} \\
(4.71)\end{array}$ & $\begin{array}{c}0.0004^{* * *} \\
(2.69)\end{array}$ & $\begin{array}{c}0.0042^{* * *} \\
(4.08)\end{array}$ \\
\hline Eid-ul-Fitr Post-holiday effect & $\begin{array}{c}0.0003^{\star *} \\
(2.03)\end{array}$ & $\begin{array}{c}0.0006 \\
(0.55)\end{array}$ & $\begin{array}{c}0.00006 \\
(0.29)\end{array}$ & $\begin{array}{c}0.0018^{\star *} \\
(2.12)\end{array}$ & $\begin{array}{c}0.0004^{* * *} \\
(2.61)\end{array}$ & $\begin{array}{c}0.0029^{* *} \\
(2.57)\end{array}$ \\
\hline Eid-ul-Adha Preholiday effect & $\begin{array}{c}0.0003^{\star *} \\
(2.04)\end{array}$ & $\begin{array}{c}0.0006 \\
(0.60)\end{array}$ & $\begin{array}{c}0.00002 \\
(0.15)\end{array}$ & $\begin{array}{c}0.0026^{\star *} \\
(2.57)\end{array}$ & $\begin{array}{c}0.0007^{\star * *} \\
(4.02)\end{array}$ & $\begin{array}{l}0.0021 \\
(0.93)\end{array}$ \\
\hline
\end{tabular}

Note: $\quad 1 .{ }^{*},{ }^{* *}$ and ${ }^{* * *}$ indicates level of significance at less than $10 \%, 5 \%$ and $1 \%$ level.

2 . The respective $\mathrm{z}$ values and $\mathrm{t}$ values are within the parentheses.

Table 6. Regression Results for the Sub-samples of June Effect

\begin{tabular}{|c|c|c|c|c|}
\hline \multirow[t]{3}{*}{ Anomaly } & \multicolumn{4}{|c|}{ GARCH $(1,1)$ conditional mean equations for different sub-samples } \\
\hline & \multicolumn{2}{|c|}{ January 1993 to October 1996} & \multicolumn{2}{|c|}{ November 1996 to December 2018} \\
\hline & $\mathrm{C}$ & B & C & B \\
\hline \multirow[t]{2}{*}{ June effect } & 0.0265 & 0.0560 & 0.0014 & $0.0326^{* *}$ \\
\hline & $(1.16)$ & $(0.29)$ & $(0.37)$ & $(2.36)$ \\
\hline
\end{tabular}

Note: $\quad 1 .{ }^{*},{ }^{* *}$ and ${ }^{* * *}$ indicates level of significance at less than $10 \%, 5 \%$ and $1 \%$ level.

2 . The respective $z$ values and $t$ values are within the parentheses.

ning day of week effects are negative and statistically significant only during the last sub-sample. DSE has positive and statistically significant Thursday returns for all three sub-samples. Therefore, based on the empirical findings on the full and sub-sample analysis on the Thursday effect in the DSE we can accept the Hypothesis 1 that the day of week anomaly is different from non-anomaly days. Specifically, in DSE the mean returns of the beginning days of a week (which is now Sunday) are different than the non-beginning days and they are negative that is statistically significant at less than 1 percent level. Moreover, mean returns on a Thursday of a week is different from the non-Thursday mean returns and they are positive. The statistically significant beginning day of week effect and Thurs- day effect are consistent with the findings of various international markets (Cross, 1973; Doyle \& Chen, 2009; Kamara, 1997), where the beginning days of a week have negative returns compared to other days of the week and the returns on ending days of a week are positive compared to other days of the week. The variation of the returns among different sub-samples for the beginning day of week effect and the Thursday effect confirms the proposition of AMH that DSE goes through cycles of efficiency and inefficiency. In some sub-samples the price inefficiency from the anomalies is statistically significant and some other periods they are not.

Both Eid-ul-Fitr pre and post-holiday effects are not statistically significant for the first sub-sample. Eid- 
ul-Adha preholiday effect is statistically significant only for the second sub-sample. Therefore, we can accept Hypothesis 2 that the pre- and post-holiday returns are different compared to non pre and post-holiday returns. In DSE the Eid-ul-Fitr pre- and post-holiday returns and Eid-ul-Adha pre-holiday returns are positive and higher compared to the returns on other calendar days. The higher and positive Eid-ul-Fitr and Eid-ul-Adha preand post-holiday effects are also evident in the literature of calendar anomalies of other Muslim countries. Bley and Saad (2010) and Zafar et al. (2012) found statistically significant preholiday effect for Eid-ul-Fitr and Eid-ul-Adha in Pakistan and in almost all GCC countries respectively. The finding of this study confirms that these anomalies follow the time-varying pattern suggested by $\mathrm{AMH}$, since in some of the sub-samples these anomalous effects were absent from DSE.

From the sub-sample analysis of the June effect from Table 6, it is evident that this calendar anomaly is statistically significant for the second sub-sample. Therefore, we can accept Hypotheses 3 that in the DSE the return on the month of June is higher and positive compared to other months of the year in Gregorian calendar. This finding is also similar to the findings of Ahsan and Sarkar (2013), where the authors reported statistically significant and positive returns on the month of June in the DSE for the sample period of 1987 to 2012.

The Ramadan effect is positive for one of the subsamples, but is not statistically significant; therefore, it's not presented here. Hence, the Hypothesis 4 cannot be accepted that in the DSE the mean returns in Ramadan months are different compared to other months in a Hijri calendar. Although a higher and positive return during the month of Ramadan was expected in a Muslim majority country like Bangladesh, Seyyed et al. (2005) also couldn't find any statistically significant positive Ramadan effect in the Saudi Arabian stock market, where almost 95 percent of the population is Muslim.

\subsection{Rolling Window Results for Time Varying Patterns of Calendar Anomalies}

\subsubsection{Day of Week Effect}

The Figure 3 presents the $\mathrm{z}$-values for the full sample period for the beginning days of a week. The first window starts from the year 1993 to 1997, so the first $z$ value plotted is for year 1997 and in this process, there are a total of 23 years' rolling $\mathrm{z}$ values. The beginning day of the week effect has become statistically significant since year 2008, as can be seen from the solid blue line of the rolling $\mathrm{z}$ values for the beginning-day-of-the-weekeffect crossing the red dotted lines of the $z$ values at 5 percent level of significance ( $\mathrm{z}$ value at 5 percent level of significance is 1.645). Panel A of Figure 3 indicates that the beginning day of a week, which is Sundays, (after the weekends in Bangladesh became Friday and Saturday from September 2005) generates statistically significant negative returns in the DSE, which has a time varying pattern. The $\mathrm{z}$ values also reveal that the statistically significant returns on Sundays are still negative and persistent until the end of the sample period.

Panel $\mathrm{B}$ of Figure 3 presents the $\mathrm{z}$ values from the rolling window regression analysis to examine the timevarying pattern of positive Thursday returns in the DSE. As it can be seen the plotted rolling $\mathrm{z}$ values of the positive Thursday returns illustrated by the blue solid line shows a time-varying pattern over time, where the statistical significance levels for the anomaly vary across the sample period of 1997 to 2018 . The positive Thursday returns are found to be highly statistically significant, especially for the year 2008 until 2011. Following the stock market crash of year 2011 the $\mathrm{z}$ values have declined in terms of their values, although the Thursday returns are still positive and significant at less than 5 percent level, which can be identified from the Figure 3 by the areas outside the red dotted lines of the $\mathrm{z}$ values at 5 percent level of significance. Therefore, the Hypothesis 1(a) is rejected that in the DSE the day of week effect will grow weaker over time.

\subsubsection{Pre- and Post-holiday Effect}

As it can be seen from Panel A of Figure 4 the plotted $\mathrm{z}$ values for the Eid-ul-Fitr preholiday effect are positive and statistically significant (indicated by the green solid line) for most of the sample years considered in this study. Apart from few sample periods the preholiday anomaly generated statistically significant positive anomalous returns in the DSE that has shown no sign to disappear from the stock market of Bangladesh.

Moreover, the rolling window $\mathrm{z}$ values from Panel $\mathrm{B}$ of Figure 4 for the Eid-ul-Fitr post-holiday effect indicate that the post-holiday effects for Eid-ul-Fitr, which is the most important national and religious holiday of 
Table 7. Sub-sample Analysis of Calendar Anomalies for Different Market Conditions at DSE

\begin{tabular}{lcccccc}
\hline Market conditions & $\begin{array}{c}\text { Beginning day } \\
\text { of week effect }\end{array}$ & $\begin{array}{c}\text { Thursday } \\
\text { effect }\end{array}$ & $\begin{array}{c}\text { June } \\
\text { effect }\end{array}$ & $\begin{array}{c}\text { Eid-ul-Fitr } \\
\text { pre-holiday } \\
\text { effect }\end{array}$ & $\begin{array}{c}\text { Eid-ul-Fitr } \\
\text { post-holiday } \\
\text { effect }\end{array}$ & $\begin{array}{c}\text { Eid-ul-Adha } \\
\text { pre-holiday } \\
\text { effect }\end{array}$ \\
\hline Up & -0.0003 & $0.0024^{* * *}$ & $0.0009^{* *}$ & $0.0024^{* * *}$ & $0.0017^{* * *}$ & $0.0027^{* * *}$ \\
Down & $(1.06)$ & $(3.29)$ & $(2.53)$ & $(3.63)$ & $(2.59)$ & $(2.87)$ \\
& $-0.0023^{* * *}$ & $0.0009^{* * *}$ & 0.0008 & $0.0037^{*}$ & 0.0036 & 0.0032 \\
Bubble & $(3.78)$ & $(2.84)$ & $(0.76)$ & $(1.83)$ & $(1.40)$ & $(1.43)$ \\
& -0.00001 & 0.0016 & $-0.0033^{*}$ & 0.0010 & -0.0048 & 0.0061 \\
Crash & $(-0.05)$ & $(1.25)$ & $(1.69)$ & $(0.27)$ & $(-0.53)$ & $(1.28)$ \\
Normal (excluding & $-0.0086^{* * *}$ & $0.0059^{*}$ & 0.0039 & 0.0019 & 0.0023 & -0.0011 \\
bubble and crash) & $(-3.35)$ & $(1.93)$ & $(1.51)$ & $(0.35)$ & $(0.19)$ & $(-0.12)$ \\
Pre circuit breaker & $-0.0008^{* * *}$ & $0.0001^{* * *}$ & $0.0018^{* * *}$ & $0.0033^{* * *}$ & $0.0032^{* * *}$ & $0.0027^{* * *}$ \\
& $(-3.99)$ & $(4.16)$ & $(6.58)$ & $(6.41)$ & $(4.51)$ & $(4.01)$ \\
Post circuit breaker & 0.0001 & 0.0003 & $0.0030^{* * *}$ & $0.0019^{* *}$ & $0.0018^{* *}$ & 0.0014 \\
& $(0.64)$ & $(1.24)$ & $(10.35)$ & $(1.99)$ & $(2.34)$ & $(1.51)$ \\
Pre automated trading & $-0.0012^{* * *}$ & $0.0011^{* * *}$ & $0.0014^{* * *}$ & $0.0047^{* * *}$ & $0.0018^{* *}$ & $0.0031^{* * *}$ \\
Post automated trading & $(-6.63)$ & $(5.28)$ & $(6.22)$ & $(12.35)$ & $(2.45)$ & $(4.45)$ \\
& 0.0017 & $0.0004^{*}$ & $0.0022^{* * *}$ & $0.0027^{* * *}$ & $0.0013^{*}$ & $0.0017^{*}$ \\
& $(0.79)$ & $(1.91)$ & $(7.32)$ & $(4.16)$ & $(1.76)$ & $(1.91)$ \\
& $-0.0015^{* * *}$ & $0.0010^{* * *}$ & $0.0011^{* * *}$ & $0.0048^{* * *}$ & $0.0022^{* * *}$ & $0.0030^{* * *}$ \\
& $(-7.70)$ & $(4.83)$ & $(4.46)$ & $(11.11)$ & $(2.97)$ & $(4.20)$ \\
\hline
\end{tabular}

Note: $1 .{ }^{\star},{ }^{* *}$ and ${ }^{* *}$ indicates the values are significant at less than $10 \%, 5 \%$ and $1 \%$ level respectively. 2. The corresponding $t$ values are in parentheses.
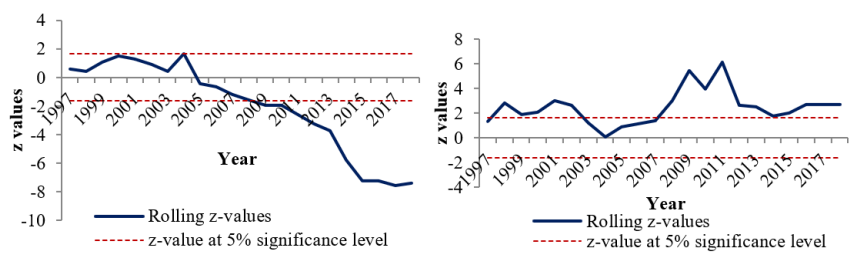

Panel A

Panel B

Figure 3. $z$-values from GARCH $(1,1)$ rolling regression analysis for beginning day of week and Thursday effect. 
Bangladesh the stock market of the country, are positive statistically significant for fifteen out of the total twenty-three years of total sample period. The Eid-ulAdha the pre-holiday effect shows a time varying pattern of statistical significance over time. The anomaly became statistically insignificant for the year 2009 to 2010 when the DSE faced the stock market bubble and again since the year 2015 until year 2018 the Eid-ulAdha pre-holiday effect is not statistically significant. Although the pre and post holiday effects are showing time-varying patterns, but based on the $\mathrm{z}$ values from the rolling regression analysis the current study could not accept the Hypothesis 2(a) that over time the positive returns from the pre- and post-holiday effects will disappear from the DSE.

\subsubsection{Month of the Year Effect}

The plotted $\mathrm{z}$ values from the rolling regression analysis on the June effect shows that this month of the year anomaly was positive and statistically significant for the first twelve years out of the total twenty-three years study period as shown in Figure 5.

However, since year 2008 the positive returns on the month of June have started to decline and the Junereturns were negative for years 2012 until 2014 following the 2011's stock market crash of the DSE. After year 2014 the June returns have become positive again, although they are still not statistically. Therefore, based on the rolling window analysis for the June effect in the DSE, we can confirm a time varying pattern in the month of June, which has also become statistically insignificant over the course of time for the observed sample period of 1997 to 2018 . Hence, we can accept the Hypothesis 3(a) that over time in the DSE June effect has disappeared from the DSE as the investors and market participants became aware of the anomalous return pattern and arbitraged away the profit from this seasonal anomaly.

Therefore, it can be inferred from the rolling window analysis of the seasonal anomalies in the DSE that the time-varying behavior is present for all of the calendar effects over the observed sample period of this current study. However, only June effect and Eid-ul-Adha pre-holiday effect have become weaker over time. Therefore, the rolling window analysis reveals the existence of AMH in the DSE in the form of time-varying pattern of market efficiency; whereas the empirical evidence (Urquhart \& McGroarty, 2014) of some developed stock markets indicate that the well established calendar anomalies have a tendency to disappear over the period of 100 years. This dissimilarity of the study results are expected according to $\mathrm{AMH}$, as the level of development of the two markets are very different including the behavior of the stock market participants of these markets.

\subsection{Impact of Changing Market Conditions on Calendar Anomalies}

\subsubsection{Up and Down Market State}

To divide the whole sample period into 'up' and 'down' markets, monthly average returns are calculated and the months with positive returns are marked as up and the months with negative returns are marked as down months (Lim et al., 2008b). Then seasonal anomalies are examined using $\mathrm{GARCH}(1,1)$ regression analysis with time dummy variables (separately for each seasonal anomaly) for up and down market states.

From Table 7 it is evident that all the seasonal anomalies that generate positive returns have positive $\beta$ coefficients in the up market condition, which are also statistically significant. In the up market state Thursday returns are positive and statistically significant; on the other hand, in the down market state the returns on the beginning days of a week are negative and statistically significant at less than 1 percent level. During the up market state the beginning day of the week anomaly is not statistically significant. The statistically significant positive returns on Thursdays, as shown in the Table 7, during the up market state are expected. However, the Thursday effect is also positive and statistically significant during the down market states, which is not expected. The up and down market states do not have any statistically significant impact on the June effect, Ramadan effect and Eid-ul-Fitr post-holiday effect. June effect is positive and statistically significant at less than 5 percent level only during the up market condition, but during the down market condition the June effect is not statistically significant. The Eid-ulFitr pre and post-holiday effect and Eid-ul-Adha preholiday effect are also found to be positive and statistically significant at less than 1 percent level during the up market condition of the DSE for the sample period of 1993 to 2018 of this current study. However, these holiday effects are not statistically significant during the down market 


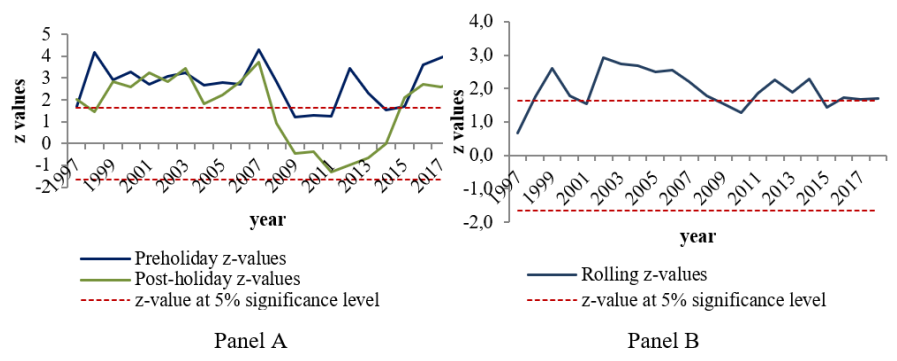

Figure 4. $z$-values from GARCH $(1,1)$ rolling regression analysis for Eid-ul-Fitr pre- and post-holiday effects and Eid-ulAdha pre-holiday effect.

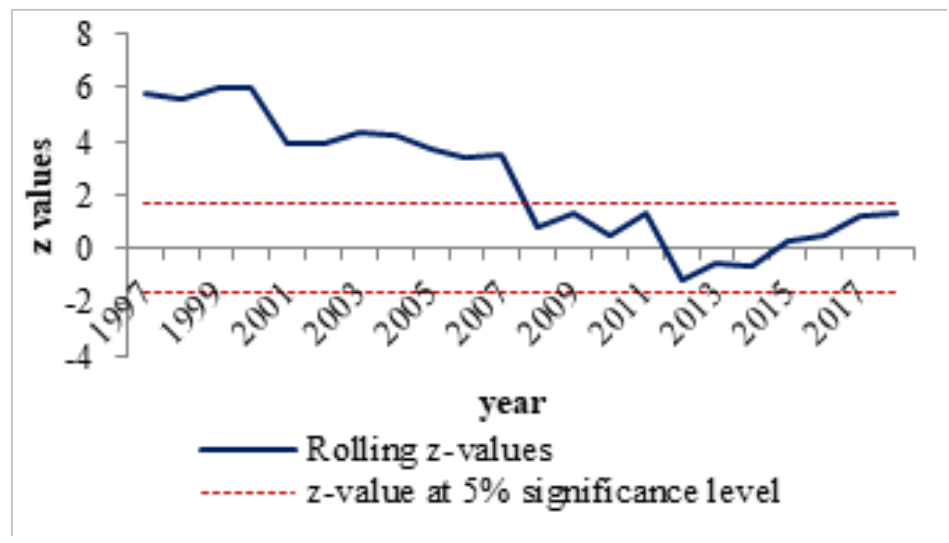

Figure 5. $z$-values from GARCH $(1,1)$ rolling regression analysis for June effect. 
conditions in the DSE. Therefore, we accept the Hypothesis 5 that the calendar anomalies vary between the up and down market state of the DSE.

\subsubsection{Bubbles, Crashes and Normal Periods}

Greenwood et al. (2017) defined that during a stock market bubble the returns on the market experiences an increase of 25 percent or more in a monthly return compared to the previous month, also the authors suggested that the market bubbles are followed by a market crash when the monthly returns decline by 25 percent or more compared to the previous month's return. The findings on the calendar anomalies suggest that both the positive and negative abnormal returns from the anomalies are statistically significant during normal market condition. Whereas, the anomaly with negative abnormal return is statistically significant during the market crash period also. However, during the market bubble none of the anomalies are statistically significant considering 5 percent level of significance. This implies that during the market bubbles the predictability of the stock returns reduces. Hence, the Hypothesis 6 is accepted that the calendar anomalies vary among the periods of stock market bubbles, crashes and normal periods.

\subsubsection{Imposition of Price Limits and Circuit Breaker System in DSE}

In general the findings on the influence of pre and post price limit and circuit breaker imposition regimes confirm that this regulatory change increases the price inefficiency in the DSE. Except for June effect all calendar anomalies are found to at least have higher $\mathrm{z}$ value after the circuit breaker and price limit are imposed. This finding is expected, since, price limits and circuit breakers cause the information to adjust slowly on the security prices and index values due to trade halt period. As a result the price discovery of the stock market is interrupted (Kim \& Yang, 2004). Therefore, the Hypothesis 7 is accepted that the calendar effects vary before and after the price limit and circuit breaker are imposed.

\subsubsection{Initiation of Automated Trading System}

The findings of the influence of the automated trading system on stock market anomalies suggest that in DSE automation of trade causes the abnormal profit patterns to become at least more statistically significant in the post regime compared to the pre automated trading system re- gime. These results are not surprising as in DSE almost 70 percent of the traders are small and individual investors (Zaman \& Rahman, 2019). They cannot efficiently and quickly analyze the available information to take advantage of high frequency trading that may improve the price discovery in the stock exchange. Therefore, the improved price discovery from full automation of the bourse could not be achieved. Hence, we can accept Hypothesis 8 that the initiation of the automated trading system in the DSE causes the stock market anomalies to vary between two regimes.

Table 8 presents the summary of the above findings of this empirical study.

\section{Conclusion}

The current study has investigated the existence of seasonal anomalies in Dhaka Stock Exchange of Bangladesh, to identify if the time-varying pattern of these calendar anomalies can explain the existence of $\mathrm{AMH}$ in the market; and whether the changed market conditions can provide explanation for these abnormal return patterns. The results of this study support the existence of AMH in the DSE of Bangladesh through time-varying behavior of seasonal anomalies and certain market conditions can explain the existence of some seasonal patterns. Therefore, the current study provides empirical evidence for the argument of Lo (2004) that change in the market regulatory structure, technological and macro environment can affect the behavior of the seasonal anomalies and as a result the level of efficiency in a stock market. In DSE, during stock market bubble and crash almost all the seasonal anomalies become statistically insignificant.

The findings of this study have important implications for the newly developed AMH theory. The current study found that changed market conditions play an important role in explaining calendar anomalies. $\mathrm{AMH}$ also states that as the investors learn from their experience and market participants know about the above average profit opportunity, the anomaly can fade away over time. However, the current study found only the June effect to disappear over time. This finding is specifically notable for the literature of $\mathrm{AMH}$, as it suggests that the adaptive nature of a market can vary depending on market specific factors and the level of development of a market, which is also accepted in AMH (Lo, 2012; Manahov \& Hudson, 2014; Urquhart \& Hudson, 2013). 
Table 8. Summary of Findings of the Study from the Empirical Analyses

\begin{tabular}{|c|c|c|c|c|}
\hline Independent Variables & Hypotheses & Hypotheses Prediction & Results & Supported \\
\hline \multirow[t]{2}{*}{ Day of week effect } & 1 & $\begin{array}{l}\text { Returns are different com- } \\
\text { pared to non-anomaly } \\
\text { days and vary over sub- } \\
\text { samples }\end{array}$ & $\begin{array}{l}\text { Negative for beginning } \\
\text { and positive for ending } \\
\text { day of week and vary over } \\
\text { subsamples }\end{array}$ & Yes \\
\hline & $1(\mathrm{a})$ & $\begin{array}{l}\text { The returns from day of } \\
\text { week will gradually fade } \\
\text { away over time }\end{array}$ & No & No \\
\hline \multirow{2}{*}{$\begin{array}{l}\text { Eid-ul-Fitr pre- and } \\
\text { post-holiday and Eid-ul- } \\
\text { Adha preholiday effect }\end{array}$} & 2 & $\begin{array}{l}\text { Returns are different com- } \\
\text { pared to non-anomaly } \\
\text { days and vary over sub- } \\
\text { samples }\end{array}$ & $\begin{array}{c}\text { Positive and varies over } \\
\text { time }\end{array}$ & Yes \\
\hline & 2(a) & $\begin{array}{l}\text { The pre- and post-holiday } \\
\text { effects from Eid-ul-Fitr } \\
\text { and Eid-ul-Adha preholi- } \\
\text { day effects will disappear } \\
\text { over time }\end{array}$ & $\begin{array}{l}\text { Only Eid-ul-Adha preholi- } \\
\text { day effect has been faded } \\
\text { away }\end{array}$ & No \\
\hline \multirow[t]{2}{*}{ June effect } & 3 & $\begin{array}{l}\text { Returns are different com- } \\
\text { pared to non-anomaly } \\
\text { months and vary over sub- } \\
\text { samples }\end{array}$ & $\begin{array}{c}\text { Positive and varies over } \\
\text { time }\end{array}$ & Yes \\
\hline & $3(\mathrm{a})$ & $\begin{array}{c}\text { The June effect will fade } \\
\text { away over time }\end{array}$ & Yes & Yes \\
\hline \multirow[t]{2}{*}{ Ramadan effect } & 4 & $\begin{array}{l}\text { Returns are different com- } \\
\text { pared to non-anomaly } \\
\text { months and vary over sub- } \\
\text { samples }\end{array}$ & Insignificant & No \\
\hline & $4(\mathrm{a})$ & $\begin{array}{c}\text { The Ramadan effect will } \\
\text { disappear over time }\end{array}$ & Untestable & Untestable \\
\hline \multirow{4}{*}{ Calendar effects } & 5 & $\begin{array}{l}\text { Varies between up and } \\
\text { down market condition }\end{array}$ & Yes. & Yes \\
\hline & 6 & $\begin{array}{l}\text { Varies among bubble, } \\
\text { crash and normal market } \\
\text { conditions }\end{array}$ & Yes. & Yes \\
\hline & 7 & $\begin{array}{l}\text { Varies between pre and } \\
\text { post circuit breaker impo- } \\
\text { sition periods }\end{array}$ & $\begin{array}{c}\text { Yes. The anomalies became } \\
\text { less significant }\end{array}$ & Yes \\
\hline & 8 & $\begin{array}{l}\text { Varies between pre and } \\
\text { post automated trading } \\
\text { initiation periods }\end{array}$ & $\begin{array}{c}\text { Yes. The anomalies became } \\
\text { more significant }\end{array}$ & Yes \\
\hline
\end{tabular}

Note: Hypothesis 4(a) is untestable since the Ramadan effect is not statistically significant in DSE. 
Emerging stock markets, for example: DSE, may require more time to adapt towards the changed market condition. Also the market participants in these markets may take longer time compared to the investors in developed markets to learn from their past investment experiences and to arbitrage away the abnormal profit opportunities. The capital market of Bangladesh has become an attractive destination for international institutional investors as they want to gain the benefit of portfolio diversification. It is logical to expect that the increased participation of foreign investors, the changes in legal environment will influence the level of market efficiency. Therefore, this study will be helpful for both local and foreign investors to formulate their investment policies in a manner that they can capture the benefits from seasonal anomalies in DSE. The regulatory bodies of DSE, for example Bangladesh Securities and Exchange Commission, can develop rules and regulations in order to address changed market environments.

\section{References}

Acharya, V. V., \& Pedersen, L. H. (2005). Asset pricing with liquidity risk. Journal of Financial Economics, 77(2), 375-410. https://doi.org/10.1016/j. jineco.2004.06.007

Agrawal, A., \& Tandon, K. (1994). Anomalies or illusions? Evidence from stock markets in eighteen countries. Journal of international Money and Finance, 13(1), 83-106. https://doi. org/10.1016/0261-5606(94)90026-4

Ahsan, A. M., \& Sarkar, A. H. (2013). Does January effect exist in Bangladesh? International Journal of Business and Management, 8(7), 82-89. https://doi. org/10.5539/ijbm.v8n7p82

Al-Hajieh, H., Redhead, K., \& Rodgers, T. (2011). Investor sentiment and calendar anomaly effects: A case study of the impact of Ramadan on Islamic Middle Eastern markets. Research in International Business and Finance, 25(3), 345-356. https://doi. org/10.1016/j.ribaf.2011.03.004

Al-Khazali, O. (2014). Revisiting fast profit investor sentiment and stock returns during Ramadan. International Review of Financial Analysis, 33(1), 158-170. https://doi.org/10.1016/j.irfa.2014.02.003

Al-Saad, K., \& Moosa, I. A. (2005). Seasonality in stock returns: evidence from an emerging market. Applied Financial Economics, 15(1), 63-71. https:// doi.org/10.1080/0960310042000281185
Alt, R., Fortin, I., \& Weinberger, S. (2011). The Monday effect revisited: An alternative testing approach. Journal of Empirical Finance, 18(3), 447-460. https://doi.org/10.1016/j.jempfin.2011.04.002

Azad, A. S., Azmat, S., Fang, V., \& Edirisuriya, P. (2014). Unchecked manipulations, price-volume relationship and market efficiency: Evidence from emerging markets. Research in International Business and Finance, 30(1), 51-71. https://doi. org/10.1016/j.ribaf.2013.05.003

Bai, J., \& Perron, P. (1998). Estimating and testing linear models with multiple structural changes. Econometrica, 47-78. https://doi. org/10.2307/2998540

Bai, J., \& Perron, P. (2003). Computation and analysis of multiple structural change models. Journal of applied econometrics, 18(1), 1-22. https://doi. org/10.1002/jae.659

Białkowski, J., Etebari, A., \& Wisniewski, T. P. (2012). Fast profits: Investor sentiment and stock returns during Ramadan. Journal of Banking \& Finance, 36(3), 835845. https://doi.org/10.1016/j.jbankfin.2011.09.014

Bley, J., \& Saad, M. (2010). Cross-cultural differences in seasonality. International Review of Financial Analysis, 19(4), 306-312. https://doi.org/10.1016/j. irfa.2010.08.004

Bo, L., \& Yong, Z. (2009). Can price limits help when the price is falling? Evidence from transactions data on the Shanghai Stock Exchange. China Economic Review, 20(1), 91-102. https://doi.org/10.1016/j. chieco.2008.09.002

Boehmer, E., \& Kelley, E. K. (2009). Institutional investors and the informational efficiency of prices. The Review of Financial Studies, 22(9), 3563-3594. https://doi.org/10.1093/rfs/hhp028

Boudreaux, D. O. (1995). The monthly effect in international stock markets: evidence and implications. Journal of Financial and Strategic Decisions, 8(1), 15-20.

Brock, W. A., \& Potter, S. M. (1993). Nonlinear time series and macroeconometrics. Handbook of statistics, 11, 195-229. https://doi.org/10.1016/ S0169-7161(05)80043-4

Broock, W. A., Scheinkman, J. A., Dechert, W. D., \& LeBaron, B. (1996). A test for independence based on the correlation dimension. Econometric reviews, 15(3), 197-235. https://doi. org/10.1080/07474939608800353

Brusa, J., Liu, P., \& Schulman, C. (2000). The weekend effect,'reverse'weekend effect, and firm size. Journal of Business Finance \& Accounting, 27(5-6), 555-574. https://doi.org/10.1111/1468-5957.00325 
Brusa, J., Liu, P., \& Schulman, C. (2005). Weekend effect,'reverse'weekend effect, and investor trading activities. Journal of Business Finance \& Accounting, 32(7-8), 1495-1517. https://doi.org/10.1111/j.0306686X.2005.00637.x

Chan, M. L., Khanthavit, A., \& Thomas, H. (1996). Seasonality and cultural influences on four Asian stock markets. Asia Pacific Journal of Management, 13(2), 1-24. https://doi.org/10.1007/BF01733814

Charles, A., Darné, O., \& Kim, J. H. (2012). Exchangerate return predictability and the adaptive markets hypothesis: Evidence from major foreign exchange rates. Journal of international Money and Finance, 31(6), 1607-1626. https://doi.org/10.1016/j. jimonfin.2012.03.003

Chordia, T., Roll, R., \& Subrahmanyam, A. (2008). Liquidity and market efficiency. Journal of Financial Economics, 87(2), 249-268. https://doi. org/10.1016/j.jfineco.2007.03.005

Cross, F. (1973). The behavior of stock prices on Fridays and Mondays. Financial analysts journal, 29(6), 6769. https://doi.org/10.2469/faj.v29.n6.67

Cui, J., Yang, Y., Cheng, G., \& Zhao, X.-j. (2008). Dissimilation of day-of-week effects between bull and bear markets-An empirical research in Chinese stock market. Systems Engineering-Theory \& Practice, 8, 17-25.

De Lima, P. J. (1996). Nuisance parameter free properties of correlation integral based statistics. Econometric reviews, 15(3), 237-259. https://doi. org/10.1080/07474939608800354

Doyle, J. R., \& Chen, C. H. (2009). The wandering weekday effect in major stock markets. Journal of Banking \& Finance, 33(8), 1388-1399. https://doi. org/10.1016/j.jbankfin.2009.02.002

Dyakova, A., \& Smith, G. (2013a). Bulgarian stock market relative predictability: BSE-Sofia stocks and South East European markets. Applied Financial Economics, 23(15), 1257-1271. https://doi.org/10.1 080/09603107.2013.802089

Dyakova, A., \& Smith, G. (2013b). The evolution of stock market predictability in Bulgaria. Applied Financial Economics, 23(9), 805-816. https://doi.org/10.1080/ 09603107.2013 .767976

Engle, R. F. (1982). Autoregressive conditional heteroscedasticity with estimates of the variance of United Kingdom inflation. Econometrica: journal of the Econometric Society, 987-1007. https://doi. org/10.2307/1912773

Fama, E. F. (1965). The behavior of stock-market prices. The journal of Business, 38(1), 34-105.

Fama, E. F. (1970). Efficient capital markets: A review of theory and empirical work. Journal of Finance, 25(2), 383-417. https://doi.org/10.1111/j.1540-6261.1970. tb00518.x

Fama, E. F. (1998). Market efficiency, long-term returns, and behavioral finance. Journal of Financial Economics, 49(3), 283-306. https://doi.org/10.1016/ S0304-405X(98)00026-9 French, K. R. (1980). Stock returns and the weekend effect. Journal of Financial Economics, 8(1), 55-69. https://doi. org/10.1016/0304-405X(80)90021-5

Gavriilidis, K., Kallinterakis, V., \& Tsalavoutas, I. (2015). Investor mood, herding and the Ramadan effect. Journal of Economic Behavior \& Organization, 132(1), 23-38. https://doi.org/10.1016/j. jebo.2015.09.018

Ghazani, M. M., \& Araghi, M. K. (2014). Evaluation of the adaptive market hypothesis as an evolutionary perspective on market efficiency: Evidence from the Tehran stock exchange. Research in International Business and Finance, 32(1), 50-59. https://doi. org/10.1016/j.ribaf.2014.03.002

Greenwood, R., Shleifer, A., \& You, Y. (2017). Bubbles for Fama. Journal of Financial Economics, Forthcoming. https://doi.org/10.1016/j.jfineco.2018.09.002

Hamilton, J. D. (1989). A new approach to the economic analysis of nonstationary time series and the business cycle. Econometrica: journal of the Econometric Society, 357-384. https://doi. org/10.2307/1912559

Hamilton, J. D. (2010). Regime switching models. In S. N. Durlauf, L. E. Blume (Eds.), Macroeconometrics and time series analysis (pp. 202-209). Palgrave Macmillan. https://doi.org/10.1057/97802302808 30_23Hassan, M., \& Khan, M. S. (2019). Day-ofweek effect on stock market return, volatility and trade volume: Evidence from Dhaka stock exchange (DSE). Journal of Finance and Banking, 15(1). https://doi.org/10.2139/ssrn.3383245

Hassan, M. H., \& Kayser, M. S. (2019). Ramadan effect on stock market return and trade volume: Evidence from Dhaka Stock Exchange (DSE). Cogent Economics \& Finance, 7(1), 1605105. https://doi.or g/10.1080/23322039.2019.1605105

Hinich, M. J. (1996). Testing for dependence in the input to a linear time series model. Journal of Nonparametric Statistics, 6(2-3), 205-221. https:// doi.org/10.1080/10485259608832672

Hiraki, T., \& Maberly, E. D. (2003). An analysis of Japanese return dynamics conditional on United States Monday holiday closures. In J. J Choi, T. Hiraki (Eds.), The Japanese Finance: Corporate Finance and Capital Markets in... (pp. 233-249): 
Emerald Group Publishing Limited. https://doi. org/10.1016/S1569-3767(03)04012-3

Hull, M., \& McGroarty, F. (2014). Do emerging markets become more efficient as they develop? Long memory persistence in equity indices. Emerging Markets Review, 18(1), 45-61. https://doi. org/10.1016/j.ememar.2013.11.001

Iqbal, M., \& Roy, J. (2015). An analysis of day-of-theweek effects in Bangladesh stock market: evidence from Dhaka stock exchange. Daffodil International University Journal of Business and Economics, 9(1), 13-25.

Islam, R., \& Sultana, N. (2015). Day of the week effect on stock return and volatility: Evidence from Chittagong stock exchange. European Journal of Business and Management, 7(3), 165-172.

Ito, M., Noda, A., \& Wada, T. (2016). The evolution of stock market efficiency in the US: a non-Bayesian time-varying model approach. Applied Economics, 48(7), 621-635. https://doi.org/10.1080/00036846.2 015.1083532

Jacobs, B. I., \& Levy, K. N. (1988). Calendar anomalies: Abnormal returns at calendar turning points. Financial analysts journal, 44(6), 28-39. https://doi. org/10.2469/faj.v44.n6.28

Jacobsen, B., \& Zhang, C. Y. (2013). Are monthly seasonals real? A three century perspective. Review of Finance, 17(5), 1743-1785. https://doi. org/10.1093/rof/rfs035

Jennings, R. H., Starks, L. T., \& Fellingham, J. C. (1981). An equilibrium model of asset trading with sequential information arrival. Journal of Finance, 36(1), 143161. https://doi.org/10.1111/j.1540-6261.1981. tb03540.x

Kamara, A. (1997). New evidence on the Monday seasonal in stock returns. Journal of Business, 1(1), 63-84.

Keef, S. P., \& Roush, M. L. (2005). Day-of-theweek effects in the pre-holiday returns of the Standard \& Poor's 500 stock index. Applied Financial Economics, 15(2), 107-119. https://doi. org/10.1080/0960310042000293164

Khwaja, A. I., \& Mian, A. (2005). Unchecked intermediaries: Price manipulation in an emerging stock market. Journal of Financial Economics, 78(1), 203-241. https://doi.org/10.1016/j. jineco.2004.06.014

Kim, C.-W., \& Park, J. (1994). Holiday effects and stock returns: Further evidence. Journal of Financial and quantitative Analysis, 29(01), 145-157. https://doi. org/10.2307/2331196

Kim, J. H., Shamsuddin, A., \& Lim, K.-P. (2011). Stock return predictability and the adaptive markets hypothesis: Evidence from century-long US data. Journal of Empirical Finance, 18(5), 868-879. https://doi.org/10.1016/j.jempfin.2011.08.002

Kim, Y. H., \& Yang, J. J. (2004). What makes circuit breakers attractive to financial markets? A survey. Financial Markets, Institutions \& Instruments, 13(3), 109-146. https://doi.org/10.1111/j.09638008.2004.00074.x

Lim, K.-P., \& Brooks, R. D. (2006). The evolving and relative efficiencies of stock markets: Empirical evidence from rolling bicorrelation test statistics. SSRN Electronic Journal. https://doi.org/10.2139/ ssrn.931071

Lim, K.-P., \& Brooks, R. D. (2009). Price limits and stock market efficiency: Evidence from rolling bicorrelation test statistic. Chaos, Solitons \& Fractals, 40(3), 1271-1276. https://doi.org/10.1016/j. chaos.2007.09.001

Lim, K.-P., Brooks, R. D., \& Hinich, M. J. (2008a). Nonlinear serial dependence and the weak-form efficiency of Asian emerging stock markets. Journal of International Financial Markets, Institutions and Money, 18(5), 527-544. https://doi.org/10.1016/j. intfin.2007.08.001

Lim, K.-P., Brooks, R. D., \& Kim, J. H. (2008b). Financial crisis and stock market efficiency: Empirical evidence from Asian countries. International Review of Financial Analysis, 17(3), 571-591. https://doi.org/10.1016/j.irfa.2007.03.001

Lim, K.-P., Luo, W., \& Kim, J. H. (2013). Are US stock index returns predictable? Evidence from automatic autocorrelation-based tests. Applied Economics, 45(8), 953-962. https://doi.org/10.1080/00036846. 2011.613782

Lo, A. W. (2004). The adaptive markets hypothesis: Market efficiency from an evolutionary perspective. Journal of Portfolio Management, 30(5), 15-29. https://doi.org/10.3905/jpm.2004.442611

Lo, A. W. (2005). Reconciling efficient markets with behavioral finance: the adaptive markets hypothesis. Journal of Investment Consulting, 7(2), 21-44.

Lo, A. W. (2012). Adaptive Markets and the New World Order (corrected May 2012). Financial analysts journal, 68(2), 18-29. https://doi.org/10.2469/faj. v68.n2.6 Manahov, V., \& Hudson, R. (2014). A note on the relationship between market efficiency and adaptability-New evidence from artificial stock markets. Expert Systems with Applications, 41(16), 7436-7454. https://doi.org/10.1016/j. eswa.2014.06.004

Marquering, W., Nisser, J., \& Valla, T. (2006). 
Disappearing anomalies: a dynamic analysis of the persistence of anomalies. Applied Financial Economics, 16(4), 291-302. https://doi. org/10.1080/09603100500400361

Mikosch, T., \& Starica, C. (2004). Changes of structure in financial time series and the GARCH model. Revstat Statistical Journal, 2(1), 41-73.

Niemczak, K., \& Smith, G. (2013). Middle Eastern stock markets: absolute, evolving and relative efficiency. Applied Financial Economics, 23(3), 181-198. https://doi.org/10.1080/09603107.2012.714068

Pástor, L., \& Stambaugh, R. F. (2003). Liquidity risk and expected stock returns. Journal of Political economy, 111(3), 642-685.

Pearson, K. (1905). The problem of the random walk. Nature, 72(1), 342. https://doi. org/10.1038/072342a0

Rahman, M. L. (2009). Stock market anomaly: Day of the week effect in Dhaka stock exchange. International Journal of Business and Management, 4(5), 193-206. https://doi.org/10.5539/ijbm.v4n5p193

Roni, B., Wu, C., Jewel, R. K., \& Wang, S. (2017). A study on the volatility of the Bangladesh stock ,arketBased on GARCH type models. Journal of Systems Science and Information, 5(3), 193-215. https://doi. org/10.21078/JSSI-2017-193-23

Schultz, P. (1985). Personal income taxes and the January effect: Small firm stock returns before the War Revenue Act of 1917: A note. Journal of Finance, 40(1), 333-343. https://doi. org/10.1111/j.1540-6261.1985.tb04954.x

Seyyed, F. J., Abraham, A., \& Al-Hajji, M. (2005). Seasonality in stock returns and volatility: The Ramadan effect. Research in International Business and Finance, 19(3), 374-383. https://doi. org/10.1016/j.ribaf.2004.12.010

Shiller, R. J. (1999). Human behavior and the efficiency of the financial system. Handbook of macroeconomics, 1(1999), 1305-1340. https://doi.org/10.1016/S15740048(99)10033-8

Shiller, R. J. (2003). From efficient markets theory to behavioral finance. The Journal of Economic Perspectives, 17(1), 83-104. https://doi. org/10.1257/089533003321164967

Smith, G. (2012). The changing and relative efficiency of European emerging stock markets. The European Journal of Finance, 18(8), 689-708. https://doi.org/1 0.1080/1351847X.2011.628682

Smith, G., \& Dyakova, A. (2014). African stock markets: efficiency and relative predictability. South African journal of economics, 82(2), 258-275. https://doi. org/10.1111/saje.12009
Thaler, R. H. (1987). Anomalies: The January effect. The Journal of Economic Perspectives, 1(1), 197-201. https://doi.org/10.1257/jep.1.1.197

Timmermann, A. (2008). Elusive return predictability. International Journal of Forecasting, 24(1), 1-18. https://doi.org/10.1016/j.ijforecast.2007.07.008

Todea, A., Ulici, M., \& Silaghi, S. (2009). Adaptive markets hypothesis: Evidence from Asia-Pacific financial markets. The Review of Finance and Banking, 1(1), 7-13.

Urquhart, A., \& Hudson, R. (2013). Efficient or adaptive markets? Evidence from major stock markets using very long run historic data. International Review of Financial Analysis, 28(2013), 130-142. https://doi. org/10.1016/j.irfa.2013.03.005

Urquhart, A., \& McGroarty, F. (2014). Calendar effects, market conditions and the Adaptive Market Hypothesis: Evidence from long-run US data. International Review of Financial Analysis, 35(2015), 154-166. https://doi.org/10.1016/j.irfa.2014.08.003

Urquhart, A., \& McGroarty, F. (2015). The adaptive market hypothesis and stock return predictability: Evidence from major stock indices. SSRN Electronic Journal. https://doi.org/10.2139/ssrn.2640934

Urquhart, A., \& McGroarty, F. (2016). Are stock markets really efficient? Evidence of the adaptive market hypothesis. International Review of Financial Analysis, 47, 39-49.

Wachtel, S. B. (1942). Certain observations on seasonal movements in stock prices. The journal of business of the University of Chicago, 15(2), 184-193.

Wong, P., Neoh, S., Lee, K., \& Thong, T. (1990). Seasonality in the Malaysian stock market. Asia Pacific Journal of Management, 7(2), 43-62. https:// doi.org/10.1007/BF01951478

Central Intelligence Agency. (2021). The World Factbook. https://www.cia.gov/the-world-factbook/static/ f0fc 26297 bcce 53 db 130339 eca 2 ed $175 /$ B G summary.pdf

Zafar, N., Urooj, S. F., Chughtai, S., \& Amjad, S. (2012). Calendar anomalies: Case of Karachi stock exchange. African Journal of Business Management, 6(24), 7261-7271.

Zaman, A., \& Rahman, M. (2019). Investment Trend Analysis of Dhaka Stock Exchange: A Comparative Study. World Academy of Science, Engineering and Technology International Journal of Economics and Management Engineering, 13(5), 758-764. 


\section{APPENDIX A}

Table 9. The Stability and Diagnostic Test Statistics for the GARCH $(1,1)$ Models to Test the Effects of the Calendar Anomalies Presented in Table 4

\begin{tabular}{|c|c|c|c|c|}
\hline \multirow{2}{*}{$\begin{array}{l}\text { GARCH }(1,1) \text { models for } \\
\text { anomalies }\end{array}$} & \multirow[t]{2}{*}{ JB test statistics } & \multirow[t]{2}{*}{ ARCH LM test } & \multicolumn{2}{|c|}{ Conditional variance equation } \\
\hline & & & $a_{1}$ & $a_{2}$ \\
\hline \multirow[t]{2}{*}{ Beginning day of the week effect } & $427873^{\star \star \star}$ & 0.0191 & $0.1460^{\star * \star}$ & $0.8539^{* * *}$ \\
\hline & & $(0.8901$ & $(29.99)$ & $(175.38)$ \\
\hline \multirow[t]{2}{*}{ Thursday effect } & $354531^{\star * *}$ & 0.0194 & $0.1461^{\star * *}$ & $0.8538^{* * *}$ \\
\hline & & $(0.889)$ & $(29.95)$ & $(175.00)$ \\
\hline \multirow[t]{2}{*}{ June effect } & $380437^{* * *}$ & 0.0197 & $0.1542^{* * *}$ & $0.8457^{\star * *}$ \\
\hline & & $(0.8883)$ & $(35.45)$ & $(194.33)$ \\
\hline \multirow[t]{2}{*}{ Ramadan effect } & $798506^{* * *}$ & 0.0496 & $0.2930^{* * *}$ & $0.7065^{\star * *}$ \\
\hline & & $(0.8237)$ & $(15.38)$ & $(65.56)$ \\
\hline \multirow[t]{2}{*}{ Eid-ul-Fitr pre-holiday effect } & $414077^{\star * *}$ & 0.0192 & $0.1490^{\star * *}$ & $0.8509^{* * *}$ \\
\hline & & $(0.8897)$ & $(35.58)$ & $(203.19)$ \\
\hline \multirow[t]{2}{*}{ Eid-ul-Fitr post-holiday effect } & $420193^{* * *}$ & 0.0196 & $0.2270^{* * *}$ & $0.7702^{* * *}$ \\
\hline & & $(0.8885)$ & $(20.02)$ & $(89.33)$ \\
\hline \multirow[t]{2}{*}{ Edi-ul-Adha pre-holiday effect } & $417471^{* * *}$ & 0.0193 & $0.1216^{* * *}$ & $0.7970^{* * *}$ \\
\hline & & $(0.8893)$ & $(3.60)$ & $(67.30)$ \\
\hline
\end{tabular}

Note: ${ }^{*}{ }^{* *}$ and ${ }^{* * *}$ indicates the coefficients are significant at less than $10 \%, 5 \%$ and $1 \%$ level.

Table 10. BDS independence test

\begin{tabular}{|c|c|c|c|c|c|}
\hline \multirow{2}{*}{$\begin{array}{l}\text { GARCH }(1,1) \text { models for } \\
\text { anomalies }\end{array}$} & \multirow[t]{2}{*}{ Dimensions } & \multicolumn{4}{|c|}{ Distance } \\
\hline & & $0.5 \sigma$ & $1 \sigma$ & $1.5 \sigma$ & $2 \sigma$ \\
\hline \multirow{3}{*}{ Beginning day of the week effect } & 2 & $0.0048^{* * *}$ & $0.0047^{* * *}$ & $0.0038^{* * *}$ & $0.0027^{\star * *}$ \\
\hline & 4 & $0.0116^{* * *}$ & $0.0087^{* * *}$ & $0.0117^{\star * *}$ & $0.0093^{* * *}$ \\
\hline & 8 & $0.0131^{* * *}$ & $0.0065^{* * *}$ & $0.0206^{* * *}$ & $0.0201^{* * *}$ \\
\hline \multirow{3}{*}{ Thursday effect } & 2 & $0.0020^{* * *}$ & $0.0035^{* * *}$ & $0.0023^{* * *}$ & $0.0011^{* * *}$ \\
\hline & 4 & $0.0019^{\star * *}$ & $0.0064^{\star * *}$ & $0.0081^{\star * \star}$ & $0.0058^{\star * *}$ \\
\hline & 8 & $0.0001^{* * *}$ & $0.0027^{\star * *}$ & $0.0102^{* * *}$ & $0.0128^{* * *}$ \\
\hline \multirow{3}{*}{ June effect } & 2 & -0.0015 & -0.0028 & -0.0017 & -0.0017 \\
\hline & 4 & 0.0001 & 0.0026 & 0.0080 & 0.0066 \\
\hline & 8 & $-0.0001^{\star * *}$ & -0.0002 & 0.0049 & 0.0132 \\
\hline \multirow{3}{*}{ Eid-ul-Fitr pre-holiday effect } & 2 & $0.0021^{* * *}$ & $0.0038^{\star * *}$ & $0.0026^{* * *}$ & $0.0013^{* * *}$ \\
\hline & 4 & $0.0011^{\star * *}$ & $0.0013^{* * *}$ & $0.0085^{\star * *}$ & $0.0058^{* * *}$ \\
\hline & 8 & $0.0001^{* * *}$ & $0.0005^{\star * *}$ & $0.0096^{* * *}$ & $0.0110^{* * *}$ \\
\hline \multirow{3}{*}{ Eid-ul-Fitr post-holiday effect } & 2 & $0.0022^{* * *}$ & $0.0039^{* * *}$ & $0.0026^{* * *}$ & $0.0012^{\star * *}$ \\
\hline & 4 & $0.0012^{\star * *}$ & $0.0070^{\star * *}$ & $0.0086^{* * *}$ & $0.0055^{\star * *}$ \\
\hline & 8 & $0.0001^{* * *}$ & $0.0027^{* * *}$ & $0.0093^{* * *}$ & $0.0098^{* * *}$ \\
\hline \multirow{3}{*}{ Edi-ul-Adha pre-holiday effect } & 2 & $0.0024^{\star * *}$ & $0.0044^{* * *}$ & $0.0029^{* * *}$ & $0.0013^{* * *}$ \\
\hline & 4 & $0.0012^{\star * *}$ & $0.0074^{* * *}$ & $0.0089^{* * *}$ & $0.0056^{* * *}$ \\
\hline & 8 & $0.0001^{\star * *}$ & $0.0030^{* * *}$ & $0.0108^{* * *}$ & $0.0117^{* * *}$ \\
\hline
\end{tabular}

Note: ${ }^{\star},{ }^{\star \star}$ and ${ }^{\star * *}$ indicates the coefficients are significant at less than $10 \%, 5 \%$ and $1 \%$ level. 


\section{APPENDIX B}

Table 11. Diagnostic test statistics for influence of different market conditions on day of week effect and month of year effect

\begin{tabular}{|c|c|c|c|c|c|c|c|c|c|}
\hline \multirow{3}{*}{$\begin{array}{l}\text { Market condi- } \\
\text { tions }\end{array}$} & \multicolumn{3}{|c|}{ Beginning day of week effect } & \multicolumn{3}{|c|}{ Thursday effect } & \multicolumn{3}{|c|}{ June effect } \\
\hline & \multirow[t]{2}{*}{ a1 } & \multirow[t]{2}{*}{ a2 } & \multirow{2}{*}{$\begin{array}{l}\text { Observed } r^{2} \\
\text { ARCH-LM }\end{array}$} & \multirow[t]{2}{*}{ a1 } & \multirow[t]{2}{*}{ a2 } & \multirow{2}{*}{$\begin{array}{l}\text { Observed } \mathbf{r}^{2} \\
\text { ARCH-LM }\end{array}$} & \multirow[t]{2}{*}{ a1 } & \multirow[t]{2}{*}{ a2 } & \multirow{2}{*}{$\begin{array}{c}{\text { Observed }{ }^{2}}^{\text {ARCH-LM }}\end{array}$} \\
\hline & & & & & & & & & \\
\hline \multirow[t]{2}{*}{ Up } & $0.2240^{* * *}$ & $0.7673^{* * *}$ & 0.0451 & $0.2241^{* * *}$ & $0.7666^{* * *}$ & 0.0477 & $0.2314^{* * *}$ & $0.7641^{* * *}$ & 0.0478 \\
\hline & $(14.44)$ & $(63.66$ & & $(14.40)$ & $(63.03)$ & & $(14.29)$ & $(62.37)$ & \\
\hline \multirow[t]{2}{*}{ Down } & $0.1659^{* * *}$ & $0.7131^{\star * *}$ & 0.0022 & $0.1455^{\star * *}$ & $0.7473^{\star * *}$ & 0.0015 & $0.1441^{* * *}$ & $0.7502^{* * *}$ & 0.0015 \\
\hline & $(11.76)$ & $(38.36)$ & & $(12.34)$ & $(48.51)$ & & $(12.29)$ & $(48.57)$ & \\
\hline \multirow[t]{2}{*}{ Bubble } & $0.6587^{* * *}$ & $0.2910^{* * *}$ & 0.1188 & $0.6612^{* * *}$ & 0.2901 & 0.0917 & $0.6527^{* * *}$ & $0.2940^{* * *}$ & 0.0974 \\
\hline & $(4.26)$ & $(3.51)$ & & $(4.28)$ & $(3.49)$ & & $(4.29)$ & $(3.55)$ & \\
\hline \multirow[t]{2}{*}{ Crash } & $0.4219^{* * *}$ & $0.4595^{* * *}$ & 0.00001 & $0.3188^{* * *}$ & $0.5784^{* * *}$ & 0.0144 & $0.3318^{* * *}$ & $0.5611^{* * *}$ & 0.0701 \\
\hline & $(3.93)$ & $(5.56)$ & & $(3.86)$ & $(8.33)$ & & $(3.93)$ & $(7.96)$ & \\
\hline Normal (excluding & $0.2270^{\star * *}$ & $0.7715^{* * *}$ & 0.0313 & $0.2292^{\star * *}$ & $0.7686^{* * *}$ & 0.0303 & $0.2261^{* * *}$ & $0.7719^{\star * *}$ & 0.0316 \\
\hline bubble and crash) & $(18.34)$ & $(80.36)$ & & $(18.27)$ & $(78.64)$ & & $(18.27)$ & $(80.47)$ & \\
\hline \multirow[t]{2}{*}{ Pre circuit breaker } & $0.1595^{\star * *}$ & $0.8404^{* * *}$ & 0.0078 & $0.1609^{* * *}$ & $0.8390^{* * *}$ & 0.0081 & $0.1856^{\star * *}$ & $0.8143^{\star * *}$ & 0.0065 \\
\hline & $(15.47)$ & $(81.52)$ & & $(15.11)$ & $(81.18)$ & & $(23.24)$ & $(101.00)$ & \\
\hline \multirow[t]{2}{*}{ Post circuit breaker } & $0.1412^{\star * *}$ & $0.8587^{* * *}$ & 0.0083 & $0.1400^{* * *}$ & $0.8599^{* * *}$ & 0.0067 & $0.1411^{\star * *}$ & $0.8588^{* * *}$ & 0.0079 \\
\hline & $(26.54)$ & $(161.40)$ & & $(25.02)$ & $(153.00)$ & & $(26.72)$ & $(162.60)$ & \\
\hline Pre automated & $0.1500^{\star * *}$ & $0.6000^{* * *}$ & 1.2586 & $0.1737^{\star * *}$ & $0.8262^{* * *}$ & 0.0054 & $0.1744^{* * *}$ & $0.8255^{\star * *}$ & 0.0045 \\
\hline trading & $(3.76)$ & $(5.96)$ & & $(20.81)$ & $(98.97)$ & & $(20.92)$ & $(99.03)$ & \\
\hline Post automated & $0.1284^{\star * *}$ & $0.8717^{\star * *}$ & 0.0188 & $0.1278^{\star * *}$ & $0.8721^{\star * *}$ & 0.0170 & $0.1265^{\star * *}$ & $0.8734^{\star * *}$ & 0.0173 \\
\hline trading & $(20.16)$ & $(137.00)$ & & (20.09) & $(137.11)$ & & (19.85) & $(137.02)$ & \\
\hline
\end{tabular}

Note: $\quad 1 .^{* *}$ indicates significant at less than $1 \%$ level of significance.

2. $\alpha 1$ and $\alpha 2$ are the ARCH and GARCH coefficients, respectively from the GARCH $(1,1)$ regression models.

3. The corresponding t-values are within the parentheses.

4. The observed r-squares from the ARCH-LM tests are not statistically significant at less than $10 \%$ level of significance. 
Table 12. Diagnostic test statistics for influence of market conditions on holiday effects

\begin{tabular}{|c|c|c|c|c|c|c|c|c|c|}
\hline $\begin{array}{l}\text { Market con- } \\
\text { ditions }\end{array}$ & \multicolumn{3}{|c|}{ Eid ul Fitr pre-holiday effect } & \multicolumn{3}{|c|}{ Eid ul Fitr post-holiday effect } & \multicolumn{3}{|c|}{ Eid ul Adha pre-holiday effect } \\
\hline & a1 & $a 2$ & $\begin{array}{c}\text { Observed } \mathbf{r}^{2} \\
\text { ARCH-LM }\end{array}$ & a1 & $\mathbf{a 2}$ & $\begin{array}{l}\text { Observed } \mathbf{r}^{2} \\
\text { ARCH-LM }\end{array}$ & a1 & $a 2$ & $\begin{array}{c}\text { Observed } \mathbf{r}^{2} \\
\text { ARCH-LM }\end{array}$ \\
\hline Up & $\begin{array}{c}0.2221^{* * *} \\
(14.49)\end{array}$ & $\begin{array}{c}0.7685^{* * *} \\
(64.38)\end{array}$ & 0.0430 & $\begin{array}{c}0.1494^{* * *} \\
(21.15)\end{array}$ & $\begin{array}{l}0.8505^{\star * *} \\
9120.43)\end{array}$ & 0.0222 & $\begin{array}{c}0.2267^{* * *} \\
(14.46)\end{array}$ & $\begin{array}{c}0.7642^{* * *} \\
(67.72)\end{array}$ & 0.0454 \\
\hline Down & $\begin{array}{c}0.1415^{\star * *} \\
(12.18)\end{array}$ & $\begin{array}{c}0.7551^{\star * \star} \\
(46.48)\end{array}$ & 0.0013 & $\begin{array}{c}0.1433^{* * *} \\
(12.36)\end{array}$ & $\begin{array}{c}0.7521^{\star * *} \\
(49.45)\end{array}$ & 0.0014 & $\begin{array}{c}0.1456^{\star * *} \\
(12.33)\end{array}$ & $\begin{array}{c}0.7485^{* * *} \\
(48.31)\end{array}$ & 0.0015 \\
\hline Bubble & $\begin{array}{c}0.6582^{* * *} \\
(4.28)\end{array}$ & $\begin{array}{c}0.2914^{* * *} \\
(3.51)\end{array}$ & 0.1205 & $\begin{array}{c}0.6462^{* * *} \\
(4.60)\end{array}$ & $\begin{array}{c}0.3357^{* * *} \\
(4.43)\end{array}$ & 0.1362 & $\begin{array}{c}0.6810^{* * *} \\
(4.27)\end{array}$ & $\begin{array}{c}0.2774^{* * *} \\
(3.45)\end{array}$ & 0.1523 \\
\hline Crash & $\begin{array}{c}0.3423^{* * *} \\
(3.79)\end{array}$ & $\begin{array}{c}00.5513^{* * *} \\
(7.33)\end{array}$ & 0.0290 & $\begin{array}{c}0.3382^{* * *} \\
(3.82)\end{array}$ & $\begin{array}{c}0.5519^{* * *} \\
(7.58)\end{array}$ & 0.0460 & $\begin{array}{c}0.3380^{* * *} \\
(3.81)\end{array}$ & $\begin{array}{c}0.5538^{* * *} \\
(7.62)\end{array}$ & 0.0400 \\
\hline $\begin{array}{l}\text { Normal (excluding } \\
\text { bubble and crash) }\end{array}$ & $\begin{array}{c}0.2241^{* * *} \\
(18.37)\end{array}$ & $\begin{array}{c}0.7735^{\star * *} \\
(81.47)\end{array}$ & 0.0309 & $\begin{array}{c}0.2296^{* * *} \\
(18.32)\end{array}$ & $\begin{array}{c}0.7699^{* * *} \\
(79.65)\end{array}$ & 0.0308 & $\begin{array}{c}0.2312^{* * *} \\
(18.44)\end{array}$ & $\begin{array}{c}0.7676^{* * *} \\
(76.21)\end{array}$ & 0.0310 \\
\hline Pre circuit breaker & $\begin{array}{c}0.1604^{* * *} \\
(15.53)\end{array}$ & $\begin{array}{c}0.8395^{* * *} \\
(81.24)\end{array}$ & 0.0078 & $\begin{array}{c}0.1614^{* * *} \\
(15.56)\end{array}$ & $\begin{array}{c}0.8385^{\star * *} \\
(80.83)\end{array}$ & 0.0069 & $\begin{array}{c}0.1618^{* * *} \\
(15.65)\end{array}$ & $\begin{array}{c}0.8381^{* * *} \\
(81.06)\end{array}$ & 0.0076 \\
\hline Post circuit breaker & $\begin{array}{c}0.1388^{* * *} \\
(24.86)\end{array}$ & $\begin{array}{c}0.8611^{* * *} \\
(154.14)\end{array}$ & 0.0077 & $\begin{array}{c}0.1394^{* * *} \\
(24.89)\end{array}$ & $\begin{array}{c}0.8605^{* * *} \\
(153.66)\end{array}$ & 0.0074 & $\begin{array}{c}0.1425^{* * *} \\
(26.88)\end{array}$ & $\begin{array}{c}0.8574^{* * *} \\
(161.64)\end{array}$ & 0.0078 \\
\hline $\begin{array}{l}\text { Pre automated } \\
\text { trading }\end{array}$ & $\begin{array}{c}0.1731^{* * *} \\
(20.77)\end{array}$ & $\begin{array}{c}0.8268^{\star * *} \\
(99.17)\end{array}$ & 0.0051 & $\begin{array}{c}0.1739^{* * *} \\
(20.78)\end{array}$ & $\begin{array}{c}0.8260^{\star * *} \\
(98.71)\end{array}$ & 0.0041 & $\begin{array}{c}0.1736^{* * *} \\
(20.84)\end{array}$ & $\begin{array}{c}0.8263^{* * *} \\
(99.18)\end{array}$ & 0.0048 \\
\hline $\begin{array}{l}\text { Post automated } \\
\text { trading }\end{array}$ & $\begin{array}{c}0.1259^{* * *} \\
(20.01)\end{array}$ & $\begin{array}{c}0.8740^{* * *} \\
(138.85)\end{array}$ & 0.0174 & $\begin{array}{c}0.1272^{* * *} \\
(19.98)\end{array}$ & $\begin{array}{c}0.8727^{\star * *} \\
(137.08)\end{array}$ & 0.0171 & $\begin{array}{c}0.1302^{* * *} \\
(21.02)\end{array}$ & $\begin{array}{c}0.8697^{* * *} \\
(140.39)\end{array}$ & 0.0172 \\
\hline $\begin{array}{l}\text { 1. } \\
\text { 2. } a 1 \\
\text { 3. Th }\end{array}$ & $\begin{array}{l}\text { ndicates sig } \\
\text { nd } \alpha 2 \text { are th } \\
\text { correspond }\end{array}$ & $\begin{array}{l}\text { ificant at les } \\
\text { ARCH and } \\
\text { g t-values a }\end{array}$ & $\begin{array}{l}\text { than } 1 \% \text { level o } \\
\text { GARCH coeffic } \\
\text { e within the par }\end{array}$ & $\begin{array}{l}\text { significanc } \\
\text { ents, respect } \\
\text { entheses. }\end{array}$ & vely from & he GARCH $(1,1$ & regression & nodels. & \\
\hline
\end{tabular}

